\title{
THE NEED FOR LEGAL IMPROVEMENT OF CIVIL LIABILITY FOR THE GUARANTEE OF THE HUMAN RIGHT TO ACCESS TO WATER AS AN ESSENTIAL PUBLIC SERVICE IN BRAZIL: AN ANALYSIS BASED ON THE SÃO PAULO WATER CRISIS (2014-2016) ${ }^{1}$
}

\author{
Gabriela Garcia Batista Lima Moraes \\ Professora Adjunta da Faculdade de Direito da Universidade de Brasília. Grupo \\ de pesquisa em Direito, Recursos Naturais e Sustentabilidade - GERN (UnB) \\ gabrielalima@unb.br/gblima@gmail.com
}

André Augusto Giuriatto Ferraço

Professor Voluntário da Faculdade de Direito da Universidade de Brasília. Grupo de pesquisa em Direito, Recursos Naturais e Sustentabilidade - GERN (UnB)

andreaugusto.gf@gmail.com

Fecha de recepción: 2 de julio de 2020 / Fecha de aceptación: 26 de octubre de 2020

\begin{abstract}
The management of the water crisis faces great complexity due to its causes and repercussions on the environment and individual rights. In Brazil, water supply can be understood as an essential service, as it guarantees the right of access to water. To better clarify the public water supply service during the crisis and its effects on individual claims for compensation filed in the São Paulo Court of Justice, the study proposes an analysis considering the Brazilian legal context in the water crisis in São Paulo, between 2014 and 2016, in order to investigate what can be improved in water supply and legal responsibility in Brazil, based on the constitutional framework and the National Water Resources Policy. The article aims to reinforce the need for legal improvement of civil
\end{abstract}

\footnotetext{
1 This study was funded by the Research Support Foundation of the Federal District (in Portuguese "Fundação de Apoio à Pesquisa do Distrito Federal, FAP-DF).
} 
responsibility applied to water management in crisis situations as a mechanism to guarantee the human right to access to water. As a result, it is argued that transparency and coherence in public water regulation are key aspects for managing the water crisis and measuring legal responsibility. The compliance to these aspects ensures the safeguarding of the principles of continuity of essential services and the supremacy of the public interest in water services.

RESUMO: A gestão da crise da água enfrenta grande complexidade devido às suas causas e repercussões sobre o ambiente e os direitos individuais. No Brasil, o abastecimento de água pode ser entendido como um serviço essencial, na medida em que garante o direito de acesso aos recursos hídricos. Para melhor clarificar o serviço público de abastecimento de água durante a crise e os seus efeitos nos pedidos individuais de indenização apresentados no Tribunal de Justiça de São Paulo, o estudo propõe uma análise considerando o contexto jurídico brasileiro na crise da água em São Paulo, entre 2014 e 2016, a fim de investigar o que pode ser aprimorado no abastecimento de água e na responsabilidade legal no Brasil, com base no marco constitucional e na Política Nacional de Recursos Hídricos. O artigo visa reforçar a necessidade de aprimoramento legal da responsabilidade civil aplicada à gestão da água em situações de crises para que se garanta o direito de acesso à água. Como resultado, sustenta-se que a transparência e a coerência na regulamentação pública da água são aspectos-chave para a gestão da crise hídrica e aferição da responsabilidade legal. A observância a esses aspectos garante a salvaguarda dos princípios da continuidade de serviços essenciais e da supremacia do interesse do público nos serviços de fornecimento de água.

RESUMEN: La gestión de la crisis del agua se enfrenta a una gran complejidad debido a sus causas y repercusiones en el medio ambiente y los derechos individuales. En el Brasil, el abastecimiento de agua puede entenderse como un servicio esencial, ya que garantiza el derecho de acceso a los recursos hídricos. Para aclarar mejor el servicio público de abastecimiento de agua durante la crisis y sus efectos en las solicitudes individuales de indemnización presentadas ante el Tribunal de Justicia de São Paulo, el estudio propone un análisis que considera el contexto jurídico brasileño en la crisis del agua en São Paulo, entre 2014 y 2016, a fin de investigar lo que se puede mejorar en el abastecimiento de agua 
y la responsabilidad jurídica en el Brasil, sobre la base del marco constitucional y la Política Nacional de Recursos Hídricos. El artículo tiene por objeto reforzar la necesidad de mejorar jurídicamente la responsabilidad civil aplicada a la gestión del agua en situaciones de crisis para garantizar el derecho de acceso al agua. En consecuencia, se sostiene que la transparencia y la coherencia en la regulación pública del agua son aspectos clave para la gestión de las crisis del agua y la medición de la responsabilidad jurídica. El cumplimiento de estos aspectos garantiza la salvaguardia de los principios de continuidad de los servicios esenciales y la supremacía del interés público en los servicios de agua.

RESUM: La gestió de la crisi de l'aigua s'enfronta a una gran complexitat a causa de les seves causes i repercussions en el medi ambient i els drets individuals. En Brasil, el proveïment d'aigua pot entendre com un servei essencial, ja que garanteix el dret d'accés als recursos hídrics. Per aclarir millor el servei públic de proveïment d'aigua durant la crisi i els seus efectes en les sol-licituds individuals d'indemnització presentades davant del Tribunal de Justícia de Són Paulo, l'estudi proposa una anàlisi que considera el context jurídic brasiler en la crisi de I'aigua a São Paulo, entre 2014 i 2016, per tal d'investigar el que es pot millorar en el proveïment d'aigua i la responsabilitat jurídica en Brasil, sobre la base de el marc constitucional i la Política Nacional de Recursos Hídrics. L'article té per objecte reforçar la necessitat de millorar jurídicament la responsabilitat civil aplicada a la gestió de l'aigua en situacions de crisi per garantir el dret d'accés a l'aigua. En conseqüència, se sosté que la transparència i la coherència en la regulació pública de l'aigua són aspectes clau per a la gestió de les crisis de l'aigua i el mesurament de la responsabilitat jurídica. El compliment d'aquests aspectes garanteix la salvaguarda dels principis de continuïtat dels serveis essencials i la supremacia de l'interès públic en els serveis d'aigua.

KEYWORDS: São Paulo water crisis - Water supply - Legal liability - Principle of continuity of essential services - Principle of the supremacy of the public interest.

PALAVRAS-CHAVE: Crise hídrica de São Paulo - Abastecimento de água Responsabilidade jurídica - Princípio da continuidade de serviços essenciais Princípio da supremacia do interesse público. 
PALABRAS CLAVE: Crisis del agua en São Paulo - Abastecimiento de agua Responsabilidad legal - Principio de continuidad de servicios esenciales Principio de la supremacía del interés público.

PARAULES CLAU: Crisi d'aigua de São Paulo - Subministrament d'aigua Responsabilitat legal - Principi de continuïtat dels serveis essencials - Principi de la supremacia de l'interès públic.

SUMARI: I. INTRODUCTION; II. THE STATE OF SÃO PAULO WATER REGULATION UNDER BRAZIL'S RULE OF LAW AND CHALLENGES ON WATER SUPPLY; 1. THE BRAZIL'S LEGAL SCENARIO FOR WATER PROVISION CHALLENGES; 2. THE STATE OF SÃO PAULO LEGAL SCENARIO FOR WATER PROVISION; III. THE NEED TO BETTER CLARIFY THE PUBLIC SERVICE OF WATER PROVISION DURING THE CRISIS; 1. THE DUTY TO PROVIDE COHERENT INFORMATION IN SÃO PAULO WATER CRISIS; 2. SÃO PAULO WATER CRISIS EFFECTS IN LEGAL CLAIMS; a. Compensation claims, the water crisis, and the major force status; $b$. The contingency tariff and contracts; $c$. The legality of the extraordinary revision of SABESP tariff for water provision given the water crisis; IV. FINAL REMARKS; V. BIBLIOGRAPHY.

\section{INTRODUCTION}

The effectiveness of providing human access to water ${ }^{2}$ is oftentimes a challenge by its own characteristics: it is a vital resource for human life, and, at the same time, it is scarce and required by different sorts of activities. To decide how these management issues will respond in a water crisis depends on a certain complex of requirements, such as providing information about the quality of the resource, dealing with conflicts of interests, compliance, infrastructure, and, particularly with the society wellbeing ${ }^{3}$.

All these general questions were observed in the São Paulo water crisis case. For this reason, the analysis of this case can contribute to reinforce the responses

\footnotetext{
2 The right of access to water is recognized as a human right. The Right to Water has multiple dimensions, such as individual (e.g. health and food), collective (e.g. development, culture, and traditional beliefs) and environmental (e.g. conservation and availability for present and future generations). In that regard: UNITED NATIONS. United Nations Resolution 64/292 The Human Right to Water and Sanitation. UN General Assembly Resolution A/RES/64/292, 2010; UNITED NATIONS HUMAN RIGHTS COUNCIL (UNHR). Report of the Special Rapporteur on the human right to safe drinking water and sanitation (On Affordability). UN Document A/HRC/30/39, 2015. 3 In this sense: DIETZ, Thomas; OSTROM, Elinor; STERN, Paul C., The Struggle to Govern the Commons. Science, 00368075, 12/12/2003, Vol. 302, no 5652; OSTROM, Elinor, "A diagnostic approach for going beyond panaceas", Proc Natl Acad Sci, 2007, September 25; 104(39), p. 15181-15182.; HERSCOVICl, Alain, "Escolha coletiva, governança e direitos de propriedade: uma análise econômica dos commons", Nova econ. [online]. 2013, vol.23, n.1, p. 192-193.
} 
of legal water management in a crisis scenario. Within these general issues, the focus of this analysis considers Brazil's legal context in the water crisis in São Paulo, in 2014 to 2016 to question what has to be improved on the water provision and legal liability, while controlling a water crisis. This analysis is based on the Brazilian constitutional provisions, the National Water Resources Policy and the jurisprudence on environmental civil responsibility.

From 2014 to 2016, the state of São Paulo in Brazil suffered with one of its worst water crises. A collapse in water planning was created because of its scarcity in one of its main water reservoirs, the "Cantareira" System and the "Alto Tietê". The "Cantareira" System was the most affected one: on May 2014, the water level was at $9,8 \%$ of its capability; on October 2014, it was at 5,8\%; on May 2015, it became negative (using the technical reserve of water, which needs to be pumped) at $-9,6 \%$ of its total capacity; on October 2015, it remained negative, at $-12,6 \%$. The "Alto Tietê" system was the second most affected one: starting at October 2014, with the water level at $11 \%$ of its capacity; on October 2015, it was in $15,5 \%$ of its capacity, and started to stabilize in $2016^{4}$.

The likely causes for the crisis were raised ${ }^{5}$ within the absence of the rainfall in the region, climate changing and their repercussion in precipitation patterns ${ }^{6}$, irregular uses of the water ${ }^{7}$, irregular occupations ${ }^{8}$, deforestation ${ }^{9}$, land uses and

\footnotetext{
${ }^{4}$ These indices can be consulted by informing the correspondent dates in the system available at: SABESP, Situação dos Mananciais, available at: http://www2.sabesp.com.br/mananciais/DivulgacaoSiteSabesp.aspx

${ }^{5}$ ZIEGLER, M. F. "Cinco razões (que não a falta de chuva) para explicar a crise hídrica em SP", IG, 25 February, 2015, available at: http://ultimosegundo.ig.com.br/brasil/2015-01-25/cincorazoes-que-nao-a-falta-de-chuva-para-explicar-a-crise-hidrica-em-sp.html

6 SABESP. Crise Hídrica, Estratégia e Soluções da Sabesp, 04.30.2015. Available at: http://site.sabesp.com.br/site/uploads/file/crisehidrica/chess_crise_hidrica.pdf

7 SORIANO, E.; LONDE, L. de R.; DI GREGORIO, L. T.; COUTINHO, M. P.; SANTOS, L. B. L., "Crise hídrica em São Paulo sob o ponto de vista dos desastres", Ambiente \& Sociedade, São Paulo v. XIX, n. 1, p. 21-42, jan.-mar. 2016, available at: http://www.scielo.br/pdf/asoc/v19n1/pt_1809-4422-asoc-19-01-00021.pdf

${ }^{8} \mathrm{JACOBI}$, P. R.; CIBIM, J.; LEÃO, R. de S. "Crise hídrica na Macropetrópole Paulista e respostas da sociedade civil", Estudos Avançados 29 (84), 2015, available at: http://www.scielo.br/pdf/ea/v29n84/0103-4014-ea-29-84-00027.pdf

9 The relation between deforestation and water crisis was also recognized as existent in the Cantareira System crisis in São Paulo, in the Ordinary Civil Action (n2536) at the Federal Supreme Court of Brazil (from Portuguese, "Supremo Tribunal Federal", STF). The Federal Supreme Court. "Ação Civil Ordinária" n 2536. Rapporteur Minister Luiz Fux. Decision published at 06.15.2015, available at: http://www.stf.jus.br/portal/processo/verProcessoAndamento.asp?incidente=4656331
} 
their repercussion in underwater conservation ${ }^{10}$. The ultimate result was that the state of São Paulo needed to provide water supply alternatives such as water transposition between basins ${ }^{11}$ and reuse water production.

In the meantime, the São Paulo's population was suffering not merely with the lack of water supply, but as well with the lack of trust in the São Paulo government. The absence of transparency ${ }^{12}$ regarding the water crises raised questions around the legality of the state actions concerning emergency solutions ${ }^{13}$ and contingency tariffs ${ }^{14}$. Through a legal analysis, the crisis of São Paulo has had uncovered the need to improve water provision regulation in a crisis scenario, especially in the concerns of transparency in public service, contingency measures, compensation, and liability issues.

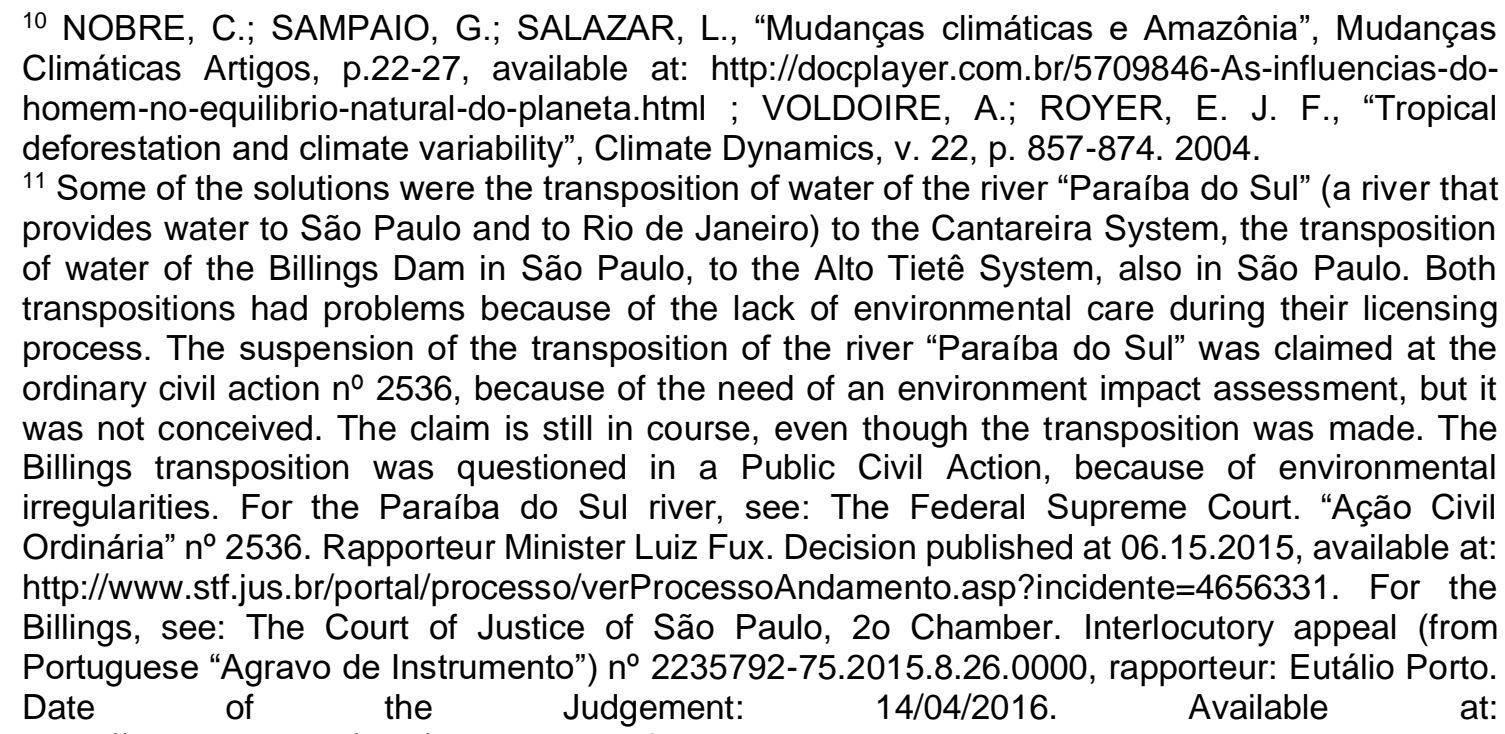
https://esaj.tjsp.jus.br/cjsg/getArquivo.do?cdAcordao=9368152\&cdForo $=0$

12 In 2014, for example, while population claimed about the absence of water provision in several regions of São Paulo, the govern of São Paulo denied the existence of rationing measures. See: DIAS, Natália. O sistema Cantareira e a crise da água em São Paulo [livro eletrônico]: falta de transparência, um problema que persiste. Coordenadora Mariana Tamari. -- São Paulo: Artigo 19 Brasil, 2016. Available at: http://artigo19.org/wp-content/blogs.dir/24/files/2016/06/SistemaCantareira-e-a-Crise-da-\%C3\%81gua-em-S\%C3\%A3o-Paulo-2.pdf

13 The Federal Supreme Court. Ação Civil Ordinária no 2536. Rapporteur Minister Luiz Fux. Decision published at 06.15.2015, available at: http://www.stf.jus.br/portal/processo/verProcessoAndamento.asp?incidente=4656331; Also: The Court of Justice of São Paulo, 2o Chamber. Interlocutory appeal (from Portuguese "Agravo de Instrumento") n $n^{\circ}$ 2235792-75.2015.8.26.0000, rapporteur: Eutálio Porto. Date of the Judgement: 14/04/2016. Available

at: https://esaj.tjsp.jus.br/cjsg/getArquivo.do?cdAcordao=9368152\&cdForo $=0$

${ }^{14}$ For example: The Court of Justice of São Paulo, 11 1 a Chamber of Public Law. Public Civil Action no 1016142-78.2015.8.26.0053, SP. Rapporteur: Marcelo L Theodósio, Judgment day: 26/09/2017, publication: 27/09/2017. 
These facts suggested a connection between Environmental Law and Human Rights ${ }^{15}$ related to access to water. The factors that caused the water crisis and its effects on the population of São Paulo demonstrate the need to ensure environmental protection and the regularity of ecosystems so that the population is not depleted of essential resources for maintaining a healthy quality of life.

In Brazil, the human right to water is related constitutionally to the right to the quality of the environment, life, sanitation, and health. It aligns with the pattern of the inclusion of the right to water access as a human right while related with other recognized human rights, but not yet as an explicit self-standing constitutional right ${ }^{16}$. This recognition is made by providing a link between these human rights granted by the Federal Constitution, and the legal regulation in the water sector, in the environmental law sector and in the sanitation sector, among others.

The interconnection between the right to life and the quality of the environment, in the Brazilian case, is supported by article 225 of the Federal Constitution ${ }^{17}$. It establish that everyone has the right to an ecologically balanced environment, which is essential to a healthy quality of life. Moreover, it is the duty of the public power and the collectivity to defend and preserve it for present and future generations.

The connection with sanitation, health issues and human rights is also an interpretation of the Constitution. Sanitation services are related to public health control (art. 200, IV, Brazilian Federal Constitution of 1988); they are granted as public services, and they must be provided by the State considering the Brazilian federative system ${ }^{18}$. Furthermore, sanitation general guidelines must be supplied in the federal level and they can be complemented by the states and municipal

\footnotetext{
${ }^{15}$ BORRÀS, S. New Transitions from Human Rights to the Environment to the Rights of Nature. Transnational Environmental Law, 5(1), 113-143. 2016.

${ }^{16}$ LANGFORD, Malcolm; RUSSELL, Anna F. S. The Right to Water in Context. In: LANGFORD, Malcolm; RUSSELL, Anna F. S. (Eds.) The Human Right to Water. Cambridge University Press, 2017, p.04; also: MACHADO, Paulo Affonso Leme. Direito de acesso à água. São Paulo: Malheiros, 2018, p. 21-22.

17 Article 225 of the Federal Constitution of Brazil states that everyone has the right to an ecologically balanced environment, a common good to everyone and essential to the healthy quality of life. In addition, it is a State duty and a collective one to preserve it for the presents and futures generations. BRAZIL, The Federal Constitution. Available at: http://www.planalto.gov.br/ccivil_03/Constituicao/Constituicao.htm

18 The Brazilian federative system is established by the Constitution and its related regulation, which, in this case, includes the Federal Law no 11.445/2007 - the Sanitation Federal Law, updated in 2020.
} 
areas actions $^{19}$ (Federal Constitution, art. 21, XX; art. 23, IX, and art. 30, II and V) ${ }^{20}$. In consonance with the Sanitation sectorial regulation, states and the municipalities areas are responsible for the service ${ }^{21}$; they can also be offered by private actors, in a concession model (art. $8^{\circ}$ and art. 10, Federal Law $n^{\circ}$ 11.445/2007, considering the changes made by the Federal Law $\mathrm{n}^{\text {0 }}$ $\left.14.026 / 2020^{22}\right)$. The link with the right of access to water is also established according to its sector regulation: sanitation services include water supply and duties related to water quality, universal access (equity), transparency, security, efficiency in its distribution and in its integration with sanitation services, as well as environmental conservation purposes, among others (article $2^{\circ}$, I, III, VI, IX, XII, XIII, of the Federal Law no $11.445 / 2007)^{23}$.

Additionally, the human consumption as a priority in the case of water scarcity is a recognized principle in the water policy (article $1^{\circ}$, III, Federal Law $\mathrm{n}^{\circ}$ 9.433/1997).

Additionally, the human consumption as a priority in the case of a declared scarcity is a recognized as a principle in the National Water Resources Policy (article 1ํㅡㄹ III, Federal Law no 9.433/1997). In fact, the Brazilian Water Policy also provides some basis of the water legal nature that follows the main international

\footnotetext{
19 Public services actions must consider administrative general principles such as legality, impersonality, morality, publicity and efficiency, in accord with the art. 37, Federal Constitution of Brazil.

${ }^{20}$ For an understanding of the constitutional competence system for the federative Brazilian model of action and water issues, see: LEUZINGER, Márcia Dieguez; COUTINHO, Gabriel Leuzinger; SILVA, Solange Teles da. Repartição de competências legislativas e materiais no âmbito dos recursos hídricos. In: PURVIN, Guilherme (Org.). Direito Ambiental, Recursos Hídricos e Saneamento. Estudos em comemoração aos 20 anos da Política Nacional de Recursos Hídricos e aos 10 anos da Política Nacional de Saneamento. 1 ed. São Paulo: Letras Jurídicas, 2017, pp.103-117.

${ }^{21}$ Before the changes of the Federal Law $n^{\circ} 14.026 / 2020$ in the Federal Law $n^{\circ} 11.445 / 2007$, the municipal duty related to sanitation public services was affirmed by the Supreme Federal Court of Brazil (Supremo Tribunal Federal - STF, in Portuguese). It also recognized the possibility for the municipalities to have partnerships with states to make improvements in the service. See: The Federal Supreme Court. Direct action of unconstitutionality no 1.842 , rel. p/ o ac. Min. Gilmar Mendes, j. 6-3-2013, P, DJE from September 16, 2013.

${ }^{22}$ Federal Law no 11.445/2007. Available at: http://www.planalto.gov.br/ccivil_03/_ato20072010/2007/lei/L11445compilado.htm

${ }^{23}$ According with the United Nations Water Conference in "Mar del Plata", 1977 and its recognition of the right to access quality drinking water (A / RES / 32/158); the Dublin Statement on Water and Sustainable Development, International Conference on Water and the Environment, 1991 (A/CONF.151/PC/112); and the United Nations Environmental Conference in Rio de Janeiro, 1992 - the Agenda 21.
} 
standards ${ }^{24}$, such as its limited source, its economic value, and its multiple use base management.

However, in a general point of view, human consumption priority as a principle 25 that must conduct water management and its multiple use is often challenged in a water crisis, such as it was in São Paulo, which had the interference of different types of treatment in accord of a variety of water supply models (e.g. human consumption and industrial consumption). In this sense, if there is no adaptation of the rules of civil liability related to water supply in cases of water crisis, the right to access water as a human right may be jeopardized.

To better understand these arguments, after presented the state of São Paulo water regulation under Brazil's Rule of Law and challenges on water supply (II), the article analyses the need to better clarify the public service of water provision during the crisis, and its effects in compensation claims (III).

\section{THE STATE OF SÃO PAULO WATER REGULATION UNDER BRAZIL'S RULE OF LAW AND CHALLENGES ON WATER SUPPLY}

The state of São Paulo water regulation is controlled under a public law regime. Nevertheless, this regulation is also under the challenges of ruling a public common good related to human rights while providing it by a private entity and private instruments for regulation.

The challenges faced in the crisis's scenario demand a transparent water regulation regime concerning the private entity assignments and the human right involved. In this scenario, it is important to, first, understand the Brazil's legal scenario for water provision and its challenges (1), and then, to understand how it is applied to the São Paulo water regulation (2).

\footnotetext{
${ }^{24}$ Being in accord with the Principle 4 of the Dublin Statement on Water and Sustainable Development, International Conference on Water and the Environment, 1991 (A/CONF.151/PC/112).

25 In general, the priority recognition can lack enforcement due to its soft nature of a principle compared with the influence of other interests. TARLOCK, A. Dan. Water allocation and management during drought. In: RIEU-CLARKE, Alistair; ALLAN, Andrew; HENDRY, Sarah (Eds.) Routledge Handbook of Water Law and Policy. New York: Routledge Handbooks, 2017, p. $155-156$.
} 


\section{THE BRAZIL'S LEGAL FRAME FOR WATER PROVISION CHALLENGES}

In Brazil, water is a common good and it is provided as a public service, related to human rights protection, as well an environmental resource related to human life. Because of its scarcity, water provision faces some challenges such as the definition of amount of water available for human access; how much water is provided for energy and agriculture inputs; the provision for industry and commerce activities; and how the state should act in a water crisis situation to ensure water access and availability.

The Federal Constitution of Brazil recognizes the public domain of water for management purposes. The water management will be connected to the federal level of action when it concerns to federal waters ${ }^{26}$ and it will be related to states actions when it concerns to state waters domain ${ }^{27}$. It also expressed in the Constitution that water is a natural resource and a common good of all human beings, belonging to present and future generations ${ }^{28}$. Its collective nature is indivisible ${ }^{29}$, which implies that every person has the right to access water. In addition, public services must be provided by the State or private entities authorized ${ }^{30}$. These characteristics are fundamental to understand the purpose of the State when private tools and a private logic is utilized for providing water: regulation is set as essential to avoid market violations to the right to access water.

The National Policy on Water Resources (Federal Law no 9.433 of 1997) recognizes water as a scarce resource, with economic value and for multiple use $^{31}$. It also determines the priority of water for human and animals use in a situation of scarcity ${ }^{32}$. The management of the access to water resources is

\footnotetext{
26 Article 20, III. BRAZIL, The Federal Constitution. Available at: http://www.planalto.gov.br/ccivil_03/Constituicao/Constituicao.htm

27 Article 26, I. BRAZIL, The Federal Constitution. Available at: http://www.planalto.gov.br/ccivil_03/Constituicao/Constituicao.htm

${ }^{28}$ Article 225 of the Federal Constitution of Brazil. BRAZIL, The Federal Constitution. Available at: http://www.planalto.gov.br/ccivil_03/Constituicao/Constituicao.htm

${ }^{29}$ Article 81, sole paragraph, I, at the Consumers Protections Law. BRAZIL. Federal Law no. 8.078 / 1990. Available at: http://www.planalto.gov.br/ccivil_03/LEIS/L8078.htm

30 Article 175 of the Federal Constitution. BRAZIL, The Federal Constitution. Available at: http://www.planalto.gov.br/ccivil_03/Constituicao/Constituicao.htm

31 Aligned with the international perspective set by the Dublin Statement on Water and Sustainable Development, International Conference on Water and the Environment, 1991.

${ }^{32}$ Article $1^{\circ}$, I, II, III, and IV of the National Policy on Water Resources. BRAZIL, Federal Law no 9.433 of 1997. Available at: https://www.planalto.gov.br/ccivil_03/LEIS/L9433.htm
} 
essentially carried out by a command and control ${ }^{33}$ logic of instruments, namely, authorizations, permits, grants or concessions, the charging for the use of water, water management plans, among others ${ }^{34}$.

The grants for use must be conferred by the holder of the domain of the water the Federal Union for federal waters and the federated state for a state regional water. The grant or concession is an administrative act that authorizes the right to utilize the water resource and it is regulated by Resolution $n=16 / 2001$ of the National Council on Water Resources ${ }^{35}$. With a grant, an authorized company can explore the public service of water distribution and sanitation. Therefore, legal contracts between the company and final consumers or other enterprises are the main instrument for it. In a conflict involving public and private interests, the primacy of the public interest principle ${ }^{36}$ demands that the public interest prevails over the private, even if they are protected by a contract. In addition, as a public service related to life, water supply is likewise under the duties of the principle of the continuity of essential services ${ }^{37}$.

Resolving a conflict is a complex matter, especially in water crisis ${ }^{38}$. Water and sanitation are different operational sectors, but they are also intrinsic matters ${ }^{39}$ : the effectiveness of one depends in a large measure on effectiveness of the

\footnotetext{
${ }^{33}$ In accord with the Federal Constitution, article 21, XIX. BRAZIL, The Federal Constitution. Available at: http://www.planalto.gov.br/ccivil_03/Constituicao/Constituicao.htm

${ }^{34}$ Article $5^{\circ}$ of the National Policy on Water Resources. BRAZIL, Federal Law no 9.433 of 1997. Available at: https://www.planalto.gov.br/ccivil_03/LEIS/L9433.htm

35 National Council of Water Resources. Resolution №16/2001. Available at: http://www.cnrh.gov.br/index.php?option=com_content\&view=article\&id=14

${ }^{36}$ FROTA, Hidemberg Alves da. O princípio da supremacia do interesse público sobre o privado no direito positivo comparado: expressão do interesse geral da sociedade e da soberania popular. Revista de Direito Administrativo, Rio de Janeiro, v. 239, p. 45-66, jan. 2005.

${ }^{37}$ LOIOLA, Suyanne Soares. Princípio da continuidade do serviço público e a suspensão no caso de inadimplência do consumidor. Revista Jurídica UNIGRAN. Dourados, MS | v. 15 | n. 30 | Jul./Dez. 2013.; BRESSER PEREIRA, Luiz Carlos. Da administração pública burocrática à gerencial. In: Revista do Serviço Público. № 47 (1), janeiro/abril de 1996. Brasília: 1996. p. 6. Disponível em: http://www.bresserpereira.org.br/papers/1996/95.AdmPublicaBurocraticaAGerencial.pdf 38 In São Paulo, for example, the contingency tariff was applied to all contracts, and it did not consider individual particularities of each contract, except those expressed in regulation, prevailing public interest of water contingency. The Court of Justice of São Paulo, 28 Chamber of Private Law. Appeal no 1075940-23.2015.8.26.0100, Equitable claim (in Portuguese is an "Ação de Obrigação de fazer com repetição in debito"), Rapporteur: Bonilha Filho, Judgment date, 09/28/2017. Available

at: https://esaj.tjsp.jus.br/cjsg/getArquivo.do?cdAcordao $=10838233 \& \mathrm{cdForo}=0$

${ }^{39}$ LANGFORD, Malcolm; BARTRAM, Jamie; ROAF, Virginia. The Human right to Sanitation. In: LANGFORD, Malcolm; RUSSELL, Anna F. S. (Eds.) The Human Right to Water. Cambridge University Press, 2017, p.359-361.
} 
other, especially considering water supply. Hance, the regulation must be clear ${ }^{40}$ to provide an effective water supply service and transparency regarding the contractual information related to water provision. Distinctions are created once the public right to information about the water is not well provided, which can result in an insecure scenario and low effectiveness on the access to water. In addition, while the private instruments are legally bound by the stipulations between the parties - applying non-disclosure terms in contracts, the public services must attend the public interest, ensure transparency and the service contracted is compelled by regulations alternances.

In the case of São Paulo, transparency, coherence, and clarity in contingency matters are issues that were problematic. To understand it, first, it is important to comprehend the legal scenario for water provision in the state of São Paulo.

\section{THE STATE OF SÃO PAULO LEGAL SCENARIO FOR WATER PROVISION}

In the legal scenario for water supply, it is important to identify the management and regulation authorities involved, as considerably as the entity responsible for water distribution in the State of São Paulo.

The water distribution in São Paulo - which include the main critical systems ("Cantareira" System and "Alto Tietê" System) - is provided by the Sanitation Company of the state of São Paulo (in Portuguese: "Companhia de Saneamento Básico do Estado de São Paulo" - SABESP). The company was created in $1973^{41}$ and currently holds the ownership, management, and the exploration assets of any nature, aiming at the universalization of basic sanitation services in the state of São Paulo42. It is an Anonymous Company (S.A. corporation) with a mixed capital company, and it is currently responsible for the water supply and sewage collection services of 21.6 million people of 368 municipalities ${ }^{43}$. The water itself

\footnotetext{
${ }^{40}$ For a study considering the public-private engagement in water supply considering various national examples, see, among others: LANGFORD, Malcolm. Privatization and the Right to Water. In: LANGFORD, Malcolm; RUSSELL, Anna F. S. (Eds.) The Human Right to Water. Cambridge University Press, 2017, p. 501-502.

${ }^{41}$ It was created by the State of São Paulo Law no 119/1973, restructured by the State of São Paulo Law no Law no 16.525, of September 15, 2017.

42 In accord with article 2, II of the State Law no 16.525, of September 15, 2017. Available at: http://www.sabesp.com.br/sabesp/filesmng.nsf/49D32E3FC45C9A92832581B0005478F0/\$File/ law_16525_september_2017.pdf

${ }^{43}$ SABESP. Perfil. Available at: http://site.sabesp.com.br/site/interna/Default.aspx? ?secaold=505
} 
is not charged, but the treatment and distribution services. The tariff policy is governed by the state Decree № 41.446/1996, which provides for the tariff system regulation of services rendered by SABESP. Basic sanitation services are also provided under the regulations of the mentioned Federal Law $n^{0} 11.445$, of January 5, 2007.

The control is mainly made by the state regulatory agency, the São Paulo State Sanitation and Energy Regulatory Agency (in Portuguese "Agência Reguladora de Saneamento e Energia do Estado de São Paulo" - ARSESP). When the water provision engages federal waters, the National Water Agency (from Portuguese "Agência Nacional das Águas e Saneamento Básico" - ANA) must authorize it. In addition, water crises may also demand ANA's collaboration. At the state of São Paulo level, the management entity is the Department of Water and Electric Energy (in Portuguese "Departamento de Água e Energia Elétrica" - DAEE).

For the water provision, SABESP provides different categories of contracts. It considers that a commercial or an industrial demand is different of a domestic demand of water and is possible to contract different tariffs. According to São Paulo's Decree ํㅜ 41.446 / 199644, there are 4 main types of users: residential, commercial, industrial, and public. The company can establish the tariffs by contract (Article 9, $\S 1$, of the Decree). The types of contract are the Adhesion Contracts and the "Firm Demand" Contracts (in Portuguese, "contratos de demanda firme") - which is similar to Firm Fixed price contracts.

While the first type of contract is an adhesion to the previous and immutably formulated tariffs and clauses ${ }^{45}$ for water provision, in the second type of contract, the tariffs and the amount of water are negotiable ${ }^{46}$ in special conditions. The Firm Demand Contract requires a specific volume of water and it cannot be for public immovable nor residential. The Adhesion Contract is the main contract signed by individual consumers, while Firm Demand Contracts engage biggest users such as industries and commercial centers.

44 The state of São Paulo Decree no 41,446 / 1996. Available at: http://site.sabesp.com.br/uploads/file/clientes_servicos/decreto_estadual\%2041446_pdf.pdf 45 ARSESP. Deliberação n. 106 de 2009, Art. ${ }^{\circ}{ }^{\circ}$. XVII. Disponível em: "http://site.sabesp.com.br/uploads/file/clientes_servicos/deliberacao_arsesp106_13112009.pdf". 46 ARSESP. Deliberação n.ำ 106 de 2009, Art. 2º . XVI. Disponível em: "http://site.sabesp.com.br/uploads/file/clientes_servicos/deliberacao_arsesp106_13112009.pdf". 
In terms of environmental equity, there is a question of injustice in SABESP's actions concerning its different contracts aimed at different types of consumers. This is because environmental equity can be related to the adoption of measures to ensure sustainability, as a rule, market mechanisms, due to the scarcity levels that a natural resource present. However, such measures can reinforce or even create inequalities between the final beneficiaries ${ }^{47}$.

Nevertheless, in accordance with the federal regulation ${ }^{48}$, once the scarcity of water is recognized, human access must be a priority, and it must be considered when applied to different types of contracts. Also, incentive measures and mandatory measures such as rationing and extraordinary contingency tariffs are available as regulation tools in a water crisis. In this matter, the Federal Law on Sanitation (Federal Law no 11.445 , of January 5, 2007) provides the possibility of rationing procedures under critical conditions of scarcity.

Regarding the SABESP and consumers, incentive measures are discounts to consumers who economizes in water consumption. Compulsory rationing measures are planned interruptions in water supply or the pressure reduction of water flow on water plumbing supply, forcing the reduction in water consumption. Both measures have sanitary risks because of the repercussions on water quality ${ }^{49}$. Those risks are also multisectoral ones such as the risk to the quality of human drinking water; to the possibility of meeting public health requirements; to the guarantee of the water supply to the industry; and to the guarantee of the water supply considering ecological purposes ${ }^{50}$. In addition, these control issues depend on what the federal, state agencies and management entities had authorized. During the crisis of 2014-2016 in São Paulo, information, coherence, and clarity in contingency matters were in some level problematic, demonstrating the need to elucidate the public service of water provision during a crisis.

\footnotetext{
${ }^{47}$ FERRAÇO, André Augusto Giuriatto. A Insuficiência de Integração na Gestão Nacional dos Recursos Hídricos Brasileiros como Óbice Estrutural ao Desenvolvimento Sustentável. Dissertação - Mestrado em Direito. Universidade de Brasília, 2019.

48 Article 1을 III, from the Federal Law $\mathrm{n}^{\circ}$ 9.433/1997. Available at: http://www.planalto.gov.br/ccivil_03/Leis/L9433.htm

49 SABESP. Crise Hídrica, Estratégia e Soluções da Sabesp, 04.30.2015, p.13. Available at: http://site.sabesp.com.br/site/uploads/file/crisehidrica/chess_crise_hidrica.pdf

50 In this sense: HOWARTH, William. Water pollution and water quality. In: RIEU-CLARKE, Alistair; ALLAN, Andrew; HENDRY, Sarah (Eds.) Routledge Handbook of Water Law and Policy. New York: Routledge Handbooks, 2017, p. 79.
} 


\section{THE NEED TO BETTER CLARIFY THE PUBLIC SERVICE OF WATER PROVISION DURING THE CRISIS}

The regulation of the access to water and its contingency in crisis periods requests to be better clarified in order to avoid an insecurity scenario and possible violations of human rights caused by the way the public service (of water provision) is provided. The lack of legal effectiveness in the public service of water provision in the São Paulo case was related to the lack of information, whether it was about the quality and the amount of water available (1), and the water crisis effects in legal claims (2).

\section{THE DUTY TO PROVIDE COHERENT INFORMATION IN SÃO PAULO WATER CRISIS}

The situation of water scarcity in São Paulo was normalized in $2017^{51}$. Still, it was a period with insecurities around the lack of coherence on the information provided about water quantity and water quality ${ }^{52}$. There were efforts from governmental agencies such as SABESP, ANA and ARSESP ${ }^{53}$, to deal with the crisis. Nevertheless, the need to enhance regulation measures concerning information provision is important, instead of being enforced by using the judicial system. After the crisis, there was some improvement ${ }^{54}$ at some level.

\footnotetext{
${ }^{51}$ DAEE, DAEE e ANA suspendem situação de criticidade em Bacias Hídricas do Estado, 23 de fevereiro de 2017.2 Available at: http://www.daee.sp.gov.br/DAEE/index.php?view=article\&id=1847\%3Adaee-e-ana-suspendemsituacao-de-criticidade-em-bacias-hidricas-doestado\&tmpl=component\&page $=$ \&option $=$ com $\_$content

52 DIA, N. O sistema Cantareira e a crise da água em São Paulo [livro eletrônico]: falta de transparência, um problema que persiste; coordenadora Mariana Tamari. São Paulo: Artigo 19 Brasil, 2016. Available at: http://artigo19.org/wp-content/blogs.dir/24/files/2016/06/SistemaCantareira-e-a-Crise-da-\%C3\%81gua-em-S\%C3\%A3o-Paulo-2.pdf

${ }^{53}$ For example, with the creation of the Technical Advisory Group on the management of the Cantareira system.

${ }^{54}$ DIA, N. O sistema Cantareira e a crise da água em São Paulo [livro eletrônico]: falta de transparência, um problema que persiste; coordenadora Mariana Tamari. São Paulo: Artigo 19 Brasil, 2016. Available at: http://artigo19.org/wp-content/blogs.dir/24/files/2016/06/SistemaCantareira-e-a-Crise-da-\%C3\%81gua-em-S\%C3\%A3o-Paulo-2.pdf
} 
In 2014, the volume of water in the "Cantareira" System caused great concerns when the average flow $\left(11,3 \mathrm{~m}^{3} / \mathrm{s}\right)$ was the lowest since $1953^{55}$. On February 2014, a Technical Advisory Group on the management of the Cantareira system was created to monitor it, with the participation of ANA, DAEE, SABESP and the Hydrographic Basin's Committee of "Piracicaba", "Capivari" and "Jundaí" rivers and the Committee of "Alto Tietê" Basin, but it was closed in September 2014. In the management level, the authorized flow of the Cantareira System was constantly revised, with its authorized flow for water supply was progressively restricted (of $27,9 \mathrm{~m}^{3} / \mathrm{s}$ in March $2014^{56}, 19,7 \mathrm{~m}^{3} / \mathrm{s}$ in July $2014^{57}, 13,5 \mathrm{~m}^{3} / \mathrm{s}$ in March $2015^{58}$ ), forcing the engagement of contingency measures.

In February 2014, an incentive program was approved by ARSESP, by the Deliberation n-469 of February 3, 2014, establishing a goal of $20 \%$ of reduction of water consumption in 2014, compared with February 2013 to January 2014. Clients who achieve the goal would be provided with a $30 \%$ discount in the water supply service tariff ${ }^{59}$. The incentive program was approved in an emergency character and would vigor until September 2014 . But only $37 \%$ of consumers had accomplished with the goal and so the program was expanded by the ARSESP Deliberation n-480 of March 31,2014 to December $2014^{60}$. The program was also amended by ARSESP Deliberation n 514 of October 24, 2014 to provide a $30 \%$ discount for those who would reduce to $20 \%$ their consumption; $20 \%$ discount for those who would reduce by $15 \%$ their consumption and $10 \%$ discount for those who would reduce in $10 \%$ of their consumption ${ }^{61}$. Another amendment extended

\footnotetext{
${ }^{55}$ SABESP. Crise Hídrica, Estratégia e Soluções da Sabesp, 04.30.2015, p.11. Available at: http://site.sabesp.com.br/site/uploads/file/crisehidrica/chess_crise_hidrica.pdf

56 In accord with the Joint Communication of ANA and DAEE no230, of March 6, 2014, available at: $\quad$ http://arquivos.ana.gov.br/institucional/sof/GTAGCantareira/20140306_Comunicado_ANA_DAEE_n_230.pdf

57 In accord with the Joint Communication of ANA and DAEE n237, of July 1, 2014. Available at: http://arquivos.ana.gov.br/institucional/sof/GTAG-

Cantareira/20140701_Comunicado_ANA_DAEE_237.pdf

${ }^{58}$ In accord with the Joint Communication of ANA and DAEE nำ243, of March 5, 2015. Available at:

http://arquivos.ana.gov.br/imprensa/noticias/20150306042504_Oficio\%20SUP\%20394\%20DAE E.pdf

59 ARSESP. Deliberation $\mathrm{n}$-469 of February 3, 2014. Available at: http://www.arsesp.sp.gov.br/LegislacaoArquivos/ldl4692014.pdf

60 ARSESP Deliberation $\mathrm{n}-480$ of March 31,2014. Available at: http://www.arsesp.sp.gov.br/LegislacaoArquivos/ldl4802014.pdf

61 ARSESP. Deliberation n-514 of October 24, 2014. Available at: http://www.arsesp.sp.gov.br/LegislacaoArquivos/ldl5142014.pdf
} 
the Program until December 31, 2016, by the ARSESP Deliberation №615, of December 23, $2015^{62}$.

A contingency tariff was authorized by the ARSESP Deliberation $n^{\circ} 545$ of January 8,2015 . The consumer whose monthly consumption exceeded the average consumption measured during the period of February 2013 to January 2014 would pay a tariff contingency. Its amount would be about $40 \%$ or $100 \%$ in addition of the value of the tariff. The addition of $40 \%$ would be applicable to the part of consumption that exceeded to $20 \%$ of the average consumption measured in February 2013 to January 2014, and the addition of $100 \%$ would apply to the part of consumption that exceeded more than $20 \%$ of the average consumption measured. Every contract was subjected to the measure, except residences with a monthly consumption of $10 \mathrm{~m}^{3}$; hospitals, health facilities, police stations, and prisons ${ }^{63}$.

The pressure reduction of the water provided was also authorized by the ARSESP Deliberation no 545 of January 8, 2015, with the obligation of SABESP to inform consumers affected with $24 \mathrm{~h}$ of antecedence ${ }^{64}$. Information issues were associated primarily to claims about transparency on rationing measures in 2014, and on the lack of additional data about the amount of water in the "Cantareira" System in 2015.

First, during the year of 2014, the possibility of a crisis was not confirmed. Expectations about the imminence of a crisis were increasing because of management measures and the incentive program. Nevertheless, even though ANA and DAEE's restrictions on the authorized flow for water supply to be used by SABESP were of public knowledge, they were not adapted to provide a clear information of the water crisis for the population, hance the data was overly technical.

It was partially improved only in 2015, when the São Paulo State Prosecutor's Office (the SP Prosecutor's Office) required from SABESP to provide a clearer

\footnotetext{
62 ARSESP. Deliberation $\mathrm{n} \div 615$, of December 23, 2015. Available at: http://www.arsesp.sp.gov.br/LegislacaoArquivos/ldl6152015.pdf

63 ARSESP. Deliberation ํㅡ 545 of January 8, 2015, articles 2 and 3. Available at: http://www.arsesp.sp.gov.br/LegislacaoArquivos/ldl5452015.pdf

64 ARSESP Deliberation $\mathrm{n}^{\circ} 545$ of January 8, 2015, art. 8‥ Available at: http://www.arsesp.sp.gov.br/LegislacaoArquivos/ldl5452015.pdf
} 
and adapted information about the amount of water available at the "Cantareira" System. The claim was formalized in the Public Civil Action no 000593092.2014.4.03.6109, in April 2015 against ANA, DAEE and SABESP. In October $2015^{65}$, SABESP was required to provide information about the negative volume of the Cantareira System, to accomplish with information duties on the article 6 , III, of the Consumer's protection Law. To better explain, in a water reservoir, there is the water useful volume, which is the mass of water that can be used without the need for pumping it; and there is the technical reserve, which is the mass of water below the useful volume and it needs to be pumped. The useful volume of water is also the level of water originally granted by the managing department for the water production and its distribution. The technical reserve needs an extra granting of authorities and it is only in crisis cases ${ }^{66}$.

As we come back with facts in 2014 , there were not any publication concerning supplementary management measures such as planned interruptions in water supply or the pressure reduction of water flow on water plumbing supply were not announced. In fact, in 2014, the existence of these rationing measures where denied several times by the governor of São Paulo67. The problem was that, simultaneously, population in different parts of the state of São Paulo was complaining about the absence of water supply for several days, claiming about water interruptions, that they were made without any previous warning of SABESP68.

The SP Prosecutor's Office started to investigate the situation. Several investigations $^{69}$ were established during the crisis to improve information

\footnotetext{
65 In the Appeal Decisions concerning the requirements on the negative volume information. TJSP - APL: 10131972120158260053 SP 1013197-21.2015.8.26.0053, Relator: Paulo Galizia, Data de Julgamento: 19/10/2015, 10ª Câmara de Direito Público, Data de Publicação: 21/10/2015. ${ }^{66}$ For more information and illustration of these technical concepts: SABESP. Situação dos Mananciais. Available at: http://www2.sabesp.com.br/mananciais/DivulgacaoSiteSabesp.aspx

67 The existence or the possibility of rationing measures were denied by the Governor of São Paulo in February, in August and in October of 2014. G1. Veja o que Alckmin disse sobre racionamento durante crise hídrica, 15 janeiro de 2015. Available at: http://g1.globo.com/saopaulo/noticia/2015/01/veja-o-que-alckmin-disse-sobre-racionamento-durante-crise-hidrica.html ${ }^{68} \mathrm{G} 1$. Moradores reclamam de falta d'água e pedem 'racionamento oficial' em SP, 15 de outubro de 2014. Available at: http://g1.globo.com/sao-paulo/noticia/2014/10/moradores-reclamam-defalta-dagua-e-pedem-racionamento-oficial-em-sp.html; BARROS, Ana Cláudia. Levantamento aponta 618 reclamações de falta de água na capital e na Grande São Paulo. R7, 01 de outubro de 2014. Available at: https://noticias.r7.com/sao-paulo/levantamento-aponta-618-reclamacoesde-falta-de-agua-na-capital-e-na-grande-sao-paulo-09102014

${ }^{69}$ Compensation claims also increased, but it will be studied in the following item of this analyses.
} 
provisions and the public service of water supply ${ }^{70}$. For instance, on May 2014, the SP Prosecutor's Office initiated an investigation about possible violations concerning the continuity of water supply services filing the Civil Inquiry $\mathrm{n}^{0}$ 43.0739.0005266/2014-6 $6^{71}$ for information diligences from SABESP. This Inquiry was later attached to another investigation (Civil Inquiry 231/2014), in which a Crisis Management Plan was required of SABESP. This last inquiry is still on course $^{72}$. Another investigation was the Civil Inquiry $n=14.0306 .0001462 / 2014$ 2 , established on July 23,2014 . It aimed to examine the civil liability for the absence of water provision in the municipality of $\mathrm{Itu}^{73}$, but it was filed in October 2016 and the conclusion of the investigation is not accessible ${ }^{74}$. In October 2014, it was established the Civil Inquiry $\mathrm{n} \cong 14.161 .749 / 14$, also concerning interruptions in water provisions ${ }^{75}$.

The effectiveness of providing water can be considered by the parameters of Dietz, Ostrom and Stern indicators of governing the commons. Namely, the access to information that must be congruent with the decisions made about the resource, the challenge of dealing with interest conflicts, multiple strategies of inducing compliance, to provide infrastructure, and to be prepared for changes ${ }^{76}$. The institutional arrangements to provide these characteristics are complex, but

\footnotetext{
${ }^{70}$ The São Paulo state Prosecutor's Office. Consulta de Procedimentos. Available at: https://sismpconsultapublica.mpsp.mp.br/ConsultarProcedimentos/ObterProcedimentos. The Federal Prosecutor's Office. São Paulo water Crisis. Public Audience, July, 2015. Available at: http://www.mpf.mp.br/atuacao-tematica/ccr4/dados-da-atuacao/eventos/audienciapublica/audiencia-publica-crise-hidrica-sp/editalaudienciapublica crise SP.pdf

${ }^{71}$ The São Paulo state Prosecutor's Office. Civil Inquiry no 43.0739.0005266/2014-6, May 2014. Available http://www.mpsp.mp.br/portal/page/portal/comunicacao/Newsletter/imagens_newsletter/14.073 9.0005266-2014-8.pdf

72 The Inquiry was latter attached to the Civil Inquiry 14.0482.0000231/2014-1, still in course. The São Paulo state Prosecutor's Office. Civil Inquiry no 14.0482.0000231/2014-1. Available at: https://sismpconsultapublica.mpsp.mp.br/Detalhe/140482000023120141

${ }^{73}$ The São Paulo state Prosecutor's Office. Civil Inquiry no 14.0306.0001462/2014-2, established on July 23, 2014.2 Available http://www.mpsp.mp.br/portal/page/portal/comunicacao/Newsletter/imagens_newsletter/14.030 6.0001462-2014-2.pdf

${ }^{74}$ The São Paulo state Prosecutor's Office. Civil Inquiry no 14.0306.0001462/2014-2, established on July 23, 2014. Available http://www.mpsp.mp.br/portal/page/portal/comunicacao/Newsletter/imagens_newsletter/14.030 6.0001462-2014-2.pdf

75 The São Paulo state Prosecutor's Office. Civil Inquiry no14.161.749/14. Available at: http://www.mpsp.mp.br/portal/page/portal/comunicacao/Newsletter/imagens_newsletter/14.016 1.0000749-2014.pdf

${ }^{76}$ DIETZ, Thomas; OSTROM, Elinor; STERN, Paul C., The Struggle to Govern the Commons. Science, 00368075, 12/12/2003, Vol. 302, no 5652
} 
in general, command and control structures centralized in the state authority are not sufficient, and compliance strategies must vary ${ }^{77}$.

From this perspective about the effectiveness for water management, in the São Paulo's case is possible to note some issues regarding the command and control and the transparency of the information. On one hand, the control of water production was made in accord with the water available (considering ANA and DAEE restrictions). In addition, the incentive program was one of the important steps on engaging the consumers' action. Additional emergency actions for water production alternatives were coherent with the need to adjust strategies and to be prepared for changes. Furthermore, the contingency tariff that came afterwards was also coherent with the need to reduce consumption.

Nevertheless, on the other hand, there was a lack of consistency regarding the information provided to consumers about rationing measures during the year of 2014, when the crises were more problematic. While management agencies both the federal and the state - were progressively imposing restrictions to SABESP, an incentive program for reductions on water consumption was running since February 2014; complains about the absence of water supply were increasing, but rationing measures (the interruption on water supply and the reduction on the water pressure) were not formally announced, in fact, they were denied in public information until the Deliberation $n^{\circ} 545$ of January 8, 2015. In addition, water crisis was recognized officially by the government of the state of São Paulo only in August 2015, by means of the "Portaria" n 2.617, of August 17,2015 of DAEE"78. The "Portaria" declared the critical state of the "Alto Tietê" system (and not the "Cantareira" System).

The lack of coherent information on the water crisis was a problematic factor in the case of São Paulo. Although public authorities have presented some

77 DIETZ, Thomas; OSTROM, Elinor; STERN, Paul C., The Struggle to Govern the Commons. Science, 00368075, 12/12/2003, Vol. 302, № 5652; OSTROM, Elinor, "A diagnostic approach for going beyond panaceas", Proc Natl Acad Sci, 2007, September 25; 104(39), p. 15181-15182.

78 DAEE, Portaria do Superintendente DAEE-2617, de 17-8-2015, at: Diário Oficial, Poder Executivo, Seção I, terça-feira, 18 de agosto de 2015, Available at: https://www.imprensaoficial.com.br/DO/BuscaDO2001Documento_11_4.aspx?link=/2015/execu tivo\%2520secao\%2520i/agosto/18/pag_0052_F0IA3O1JBVME8eC-5E71G6I65LP9.pdf\&pagina $=52 \&$ data $=18 / 08 / 2015 \&$ caderno $=$ Executivo $\% 201$ \&paginaordenacao $=100052$ 
mechanisms for rationing water, the lack of information about the crisis does not lead to rationalization of water use.

The right to access information must be guaranteed to citizens during a water crisis. Information must be made available in a clear, accessible, and up-to-date manner. This right is essential to avoid greater instability during the crisis, as it provides access to and understanding of information on the general conjuncture of the problem, as well as the way in which individuals will be affected in their individual sphere - especially in order to allow for a planning horizon to mitigate the impacts.

As these measures were not guaranteed at the time of the crisis management, many individual complaints were presented to the judiciary. However, at the Judicial system of São Paulo, the water crises provided many unpleasant situations where people started to claim for compensation due to the interruption of water supply.

\section{SÃO PAULO WATER CRISIS EFFECTS IN LEGAL CLAIMS}

There are three main legal issues in the São Paulo water crisis effects that were questioned in Justice and that are worth's to clarify, since it is useful to better understand water regulation in a water crisis and liability rules. They are related to limits on the relation between the uses of private instruments to provide public services. These limits are provided by regulation and are crucial to avoid violations on human rights related to the water. The first one is compensation claims were limited because of the consideration of the water crisis as a major force fact (a), the second one is the reasonability of the contingency tariff and contracts (b), and the third one is applied to questions about an extraordinary revision of SABESP tariff for water provision given the water crisis (c).

\section{a. Compensation claims, the water crisis, and its major force status}

In the Judicial system of São Paulo, the water crises raised several legal requests. However, compensation claims were denied because of the argument that there was not any irregularity on the water service provision during the water 
crisis. The complexity of these claims relates to the burden of the proof, and the consideration of the water crises as a major force cause. These events can be criticized if applied in the period in which rationing measures were not formatted. In this sense, a possible technical illegality of the 2014 interruptions was not considered and water crisis was reflected only in its general perspective (as of 2014 to 2016).

Several cases were claiming compensation because of the moral and material damage related to the interruption of water provision. There were claims demanding compensation for the cost of accessing water by renting additional water tank trucks ${ }^{79}$, or because of the moral and personal damage caused by the total privation to water for weeks. There were also judicial requirements that aimed to compel SABESP to reestablish water provision, arguing the need of some reasonability because of any particularity such as the harmful conditions of the claimant because of $a g e^{80}$, for example, or because of the type of activity that was supplied with water ${ }^{81}$.

Nevertheless, the compensation was denied under the argument that the water crisis was a burden that every person was subjected to. To support these decisions, the water crisis was considered as an event of public knowledge and because of that, it was not necessary to prove it. Furthermore, claims were denied because restrictions and water privation were caused by the water crisis. In this sense "the serious water crisis that struck the State of São Paulo between 2014 and 2016 is a notorious fact (and therefore it would not even be necessary to prove - article $n^{\circ} 374$, l, of the New Code of Civil lawsuit)" ${ }^{\prime 2}$. However, this main argument can be criticized, since the burden of the proof is not solely to provide

\footnotetext{
79 The Court of Justice of São Paulo: Appeal no 1015295-87.2015.8.26.0114, 24 Chamber of Private Law. Rapporteur: Jonize Sacchi de Oliveira, Judgment day: 14/12/2017; Appeal oㅡ 1015395-42.2015.8.26.0405, 28을 Chamber of Private law. Rapporteur: Gilson Delgado Miranda, Judment date: 24/01/2018; Appeal oㅜ 1011677-90.2015.8.26.0161, 13을 Chamber of Private Law. Rapporteur: Francisco Giaquinto, Judment date: 07/07/2017; Appeal no 100590767.2014.8.26.0609, 30ํㅡㄹ Chamber of Private Law. Rapporteur: Penna Machado, Judment date: 14/12/2016; Appeal no 1000459-71.2015.8.26.0547; 10 a Chamber of Public Law. Rapporteur: Paulo Galizia; Judment date: 05/03/2018; Appeal no 1000459-71.2015.8.26.0547.

80 The Court of Justice of São Paulo. "Agravo de Instrumento" n 2207892-54.2014.8.26.0000, $5^{\text {a }}$ Chamber of Public Law. Rapporteur: Fermino Magnani Filho, Judment date: 23/07/2015.

81 The Court of Justice of São Paulo, Appeal no 1075940-23.2015.8.26.0100, 28 Chamber of Private Law. Rapporteur: Bonilha Filho, Judment date, 09/28/2017.

82 The Court of Justice of São Paulo. Appeal no 1015395-42.2015.8.26.0405, 28 ${ }^{\text {a }}$ Chamber of Private Law. Rapporteur: Gilson Delgado Miranda, Judment date: 24/01/2018.
} 
knowledge about the existence of the water crisis and its consequences, but the quality of the public service of water provision, even during the crisis. In this sense, there is the need to prove the legality of rationing measures; not only their content, but especially in what manner they were applied.

For that matter, compensation claims that were related to water privation in 2014 but were not conceived because of the argument of the presence of the water crisis are problematic. During the year of 2014, rationing measures were not official, and people were not notified when it would happen. They were official only after the ARSESP Deliberation № 545 of January 8, 2015, when it was provided the obligation of SABESP to notify the citizens with $24 \mathrm{~h}$ of antecedence about the reduction of the pressure of water. This was the case of an Appeal decided in 2016, that denied the compensation claim of moral and material damages related to pressure reduction from September 07, 2014 to October 13, 2014, that is, over than 6 weeks ${ }^{83}$.

The civil liability rules for state actions has the major force status of natural disasters facts as one of the fundaments to exclude state liability ${ }^{84}$. On the one hand, it can be criticized in its lacks of adaptation regarding the possibility to characterize water privation as an environmental damage; and, on the other hand, water privation was also due to management problems on the public service for water supply, omissions in information concerning water quality and water contingency measures. In both arguments, we must consider that water privation was proved to be not only because of the water scarcity crisis, but also because of the absence of information and the lack of transparency regarding the water crises management.

In that sense, water privation could also be considered as an environmental damage: a moral collective damage that is under the strict liability theory. It holds liable the responsible for the activity in an objective perspective, one that doesn't evaluate the actor intention of producing the result, whether it was an action or

${ }^{83}$ The Court of Justice of São Paulo. Appeal o 1005907-67.2014.8.26.0609, 30를 Chamber of Private Law. Rapporteur: Penna Machado, Judment date: 14/12/2016.

${ }^{84}$ FURTADO, Lucas Rocha. Curso de Direito Administrativo. Belo Horizonte: Fórum, 2007, p.1007. 
an omission related to a duty ${ }^{85}$; and one that is not relativized by any case of liability exclusion, including the major force status of natural disasters ${ }^{86}$. This would enhance the connection between the human right to water and the duty to improve the public service excellence to manage and supply water, within the obligation of transparency, information, and efficiency.

In the Brazilian legal norms, strict liability theory is applied in the consumers matters, which provides that the responsible for a service is fully liable for consumers damages related to its way of providing the service (articles 12 and 14, Federal Law no 8.078/1990). Furthermore, strict liability is also applied to environmental damage, according the Environmental National Public Policy law, which demands that the polluter must compensate the damage caused, regardless its intention of producing the result $\left(\$ 1^{\circ}\right.$, article 14 , Federal Law $\mathrm{n}^{\circ}$ $6.938 / 1981)$. The status of the "moral collective damage" for environmental damage is also an interpretation of the Superior Court of Justice, which recognizes the compensation for material environmental damage and for moral collective environmental damage ${ }^{87}$; nonetheless, the Court doesn't mention the possibility of its application in the case of water privation.

In this sense, the legal violations that would characterize environmental damage related to water deprivation due to omissions in management from the application of strict liability status would be based on basic rights related to water. The main ones are the disregard for the priority of human consumption in a situation of scarcity (Article 1, III, Federal Law No. 9,433/1997); the violation of universal equal access (Article 2, I, Federal Law No. 11,445/2007), and the right to a quality environment (Article 225, Federal Constitution). In the case of São Paulo, these rights were neglected due to the different treatment of consumers through special contracts, incoherent information on water quality, lack of

\footnotetext{
85 LEITE, José Rubens Morato; AYALA, Patryck de Araújo. Dano ambiental: do individual ao coletivo extrapatrimonial. Teoria e Prática. 5 ed. São Paulo: Editora Revista dos Tribunais, 2014, p. 192.

${ }^{86}$ STEIGLEDER, Annelise Monteiro. Responsabilidade civil ambiental: as dimensões do dano Ambiental no Direito Brasileiro. 3 ed. Revista e Atualizada. Porto Alegre: Editora Livraria do Advogado, 2017, p.182.

${ }^{87}$ Superior Court of Justice. REsp 1.328.753-MG, Rel. Min. Herman Benjamin: 28/5/2013.
} 
information on the implementation of contingency measures and with the omission of information on water supply in the initial period of the crisis $^{88}$.

The damages are related to the omissions in the public service of water supply. Without notification, rationing measures would be unpredictable. Therefore, implementation of rationing measures requires transparency, especially because of the effects these measures have on the regular use of water by the affected population. If these measures were applied without any notification, a violation of human rights is characterized, and compensation should be provided. It is also a strict interpretation of the article 46 of the Federal Law on Sanitation (Federal Law no 11.445, of January 5, 2007), which expresses the possibility of rationing procedures under critical conditions of scarcity and the need for it to be declared by the water resource management authority:

Art. 46. Under critical conditions of scarcity or contamination of water resources that may require the adoption of rationing procedures, to be declared by the water resource management authority, the regulatory entity may adopt contingency tariff mechanisms, in order to cover additional costs deriving from such procedure, thus assuring the financial balance of service delivery and of supply management ${ }^{89}$.

Nevertheless, this is not the judicial decisions in São Paulo's legal claims. The water crisis was equally understood a major force fact and rationing measures were rendered as necessary, no matter how it was used.

However, there is the configuration of the damage in the way the measures were applied: without notification and information about the formal and the material basis that would justify the rationing measures. This argument is in line with the

\footnotetext{
88 To remember, as we come back with facts in 2014, there were not any publication concerning supplementary management measures such as planned interruptions in water supply or the pressure reduction of water flow on water plumbing supply were not announced. In that sense: BARROS, Ana Cláudia. Levantamento aponta 618 reclamações de falta de água na capital e na Grande São Paulo. R7, 01 de outubro de 2014. Available at: https://noticias.r7.com/saopaulo/levantamento-aponta-618-reclamacoes-de-falta-de-agua-na-capital-e-na-grande-saopaulo-09102014

89 Article 46. Federal Law o 11.445 , of January 5, 2007, English version. Available at: http://www.sabesp.com.br/sabesp/filesmng.nsf/51E5FECA4D2D70A38325772300657DC5/\$File /law_11445.pdf
} 
principle of the strict legality of public actions that in this case should encompass the article 46 of the Federal Law on Sanitation as a mean to prevent human rights violation related to water access.

In this sense, the State or an enterprise authorized to provide public service such as it is the case of SABESP - is engaged with administrative law, and therefore, actions affecting fundamental rights must be provided only in accordance with what was stipulated by the norms applied. In this case, the need to inform that rationing measures are being applied and the obligation to previously notify.

Access to water is an essential public service for the regular maintenance of quality of life. A water crisis caused by the reduction of the volumes of water available for the supply of a population, in itself, already directly affects the regularity of the quality of life of those affected, since they have less than was previously provided. An even more serious violation of the rights of those affected occurs when the Public Power responsible for managing the risks and effects of this type of crisis does not provide legal certainty for the implementation of the measures necessary to contain the water crisis that affect the regularity of service for citizens.

When the normative provisions regulating the state's public activities are not observed, citizens who are already in a situation of vulnerability due to reduced access to the human right to water are subject to arbitrary state measures that lack transparency, reasonability and legality. Moreover, in the case of São Paulo there is a problem of equity and transparency in the economic instruments used for the occurrence of the crisis. This factor is perceptible in the way water supply contracts were offered to different consumers and on how the contingency tariffs were applied.

\section{b. The contingency tariff and contracts}

One of the most severe rationing measures during the crisis was the contingency tariff authorized by the ARSESP Deliberation no 545 on January 8, 2015. The consumer whose monthly consumption exceeded the average consumption measured during the period of February 2013 to January 2014 would pay $40 \%$ or 
$100 \%$ extra over the consumption value. Every contract was subjected to the measure, except for residences with a monthly consumption of $10 \mathrm{~m}^{3}$; hospitals, health facilities, police stations, and prisons ${ }^{90}$. The main problems concerning it was the lack of information about the "Firm Demand Contracts" during the crisis and the limits of the contingency tariff's application.

In this concern, SABESP faced numerous claims due to the absence of information on how rationing measures were applied to the different types of contracts. As explained before, SABESP provides water supply to the population using Adhesion Contracts or Firm Demand Contracts.

The Firm Demand Contracts (normally for industry entities) were the most criticized because they already provided special tariffs in contrast with Adhesion Contracts (normally for the average person or its house), giving $75 \%$ discount on usual tariffs, and they involved an amount of water greater than Adhesion contracts $^{91}$. In 2014, there were more than 500 Firm Demand Contracts running. In that year, the newest 16 Firm Demand Contracts signed were receiving about 120,695 million of liters of water, most of it supplied by the "Cantareira" System ${ }^{92}$. Claims were growing because SABESP refused to give information about these contracts $^{93}$, arguing that they were protected by non-disclosure terms.

The non-disclosure terms in contracts, as well as the contractual free initiatives are proper elements of private law and must be respected. However, they are not absolute or irrefutable, and they shall not be opposed to the primacy of the public interest. When a public service is provided by a private actor or using private legal tools, it does not have the same effect as providing a private good and its

\footnotetext{
90 ARSESP Deliberation $\mathrm{n}^{\circ} 545$ of January 8, 2015, articles 2 and 3 . Available at: http://www.arsesp.sp.gov.br/LegislacaoArquivos/ld15452015.pdf

${ }^{91}$ REDE BRASIL ATUAL. Sabesp divulga contratos censurados de demanda firme em seu site, 12 de março de 2015. Available at: https://www.saneamentobasico.com.br/sabesp-divulgacontratos-censurados-de-demanda-firme-em-seu-site/

92 DIAS, Natália. O sistema Cantareira e a crise da água em São Paulo [livro eletrônico]: falta de transparência, um problema que persiste. Coordenadora Mariana Tamari. -- São Paulo: Artigo 19 Brasil, 2016, p. 12. Available at: http://artigo19.org/wpcontent/blogs.dir/24/files/2016/06/Sistema-Cantareira-e-a-Crise-da-\%C3\%81gua-em-

S\%C3\%A3o-Paulo-2.pdf

${ }^{93}$ CARTA CAPITAL. Crise hídrica: As cinco perguntas que a Sabesp se recusa a responder, 25.02.2015. Disponível em: http://www.cartacapital.com.br/sociedade/as-cinco-perguntas-que-asabesp-se-recusa-a-responder-2858.html.
} 
exclusivity and characteristics, once again, because of the prevalence of public interest. In this sense:

It is true that the economic order in the Constitution of 1988 defines a system in which it plays a primordial role the free initiative. This circumstance does not, however, legitimize the assertion that the State will only intervene in the economy in exceptional situations. More than a simple instrument of government, our Constitution enunciates directives, programs, and ends to be realized by the State and by the society. It postulates a global normative action plan for the State and for society, informed by the precepts conveyed by its arts. $1^{\circ}, 3^{\circ}$ and 170 . Free enterprise is an expression of freedom entitled not only by the company, but also by the work. For this reason, the Constitution, when contemplating it, also considers the "initiative of the State"; it does not privilege it, therefore, as only pertinent to the company. If, on the one hand, the Constitution guarantees the free enterprise, on the other hand it determines to the State the adoption of all measures designed to guarantee the effective exercise of the right to education, culture and sport (articles 23, V, 205, 208, 215 and 217, paragraph 3, of the Constitution). In the composition between these principles and rules, the interest of the collectivity, the primary public interest must be preserved." 94

Moreover, it is possible to provide the public information required without compromising non-disclosure terms. With the argument that water supply is a

${ }^{94}$ Free translation from Portuguese. The original: "É certo que a ordem econômica na Constituição de 1988 define opção por um sistema no qual joga um papel primordial a livre iniciativa. Essa circunstância não legitima, no entanto, a assertiva de que o Estado só intervirá na economia em situações excepcionais. Mais do que simples instrumento de governo, a nossa Constituição enuncia diretrizes, programas e fins a serem realizados pelo Estado e pela sociedade. Postula um plano de ação global normativo para o Estado e para a sociedade, informado pelos preceitos veiculados pelos seus arts. 1ำ $3^{\circ}$ e 170. A livre iniciativa é expressão de liberdade titulada não apenas pela empresa, mas também pelo trabalho. Por isso a Constituição, ao contemplá-la, cogita também da "iniciativa do Estado"; não a privilegia, portanto, como bem pertinente apenas à empresa. Se de um lado a Constituição assegura a livre iniciativa, de outro determina ao Estado a adoção de todas as providências tendentes a garantir o efetivo exercício do direito à educação, à cultura e ao desporto (arts. 23, V, 205, 208, 215 e 217, § 3o, da Constituição). Na composição entre esses princípios e regras há de ser preservado o interesse da coletividade, interesse público primário". Information available at: Federal Superior Court, Direct action of unconstitutionality no 1.950, Rel. Min. Eros Grau, j. 3-11-2005, P, DJ de 26-2006. 
matter of public interest, the SP District Prosecutor ${ }^{95}$, based on the Access to Information Law, required the publication of information on Firm Demand contracts. After that order, SABESP presented them, however, they were published without data on consumption and the amounts charged for the use of water. There were 613 contracts published in March $2015^{96}$.

Subsequently, in the São Paulo Court, another issue related to the contingency tariff was its reasonability in a lawsuit involving a school and its Firm Demand Contract. The school attorney was claiming for compensation for the excessive amount paid due to the contingency tariff. He questioned that it was unfair to apply the contingency tariff to ordinary school periods if the tariff was calculated in vacation periods when the demand of water was low. He also claimed for more reasonability in the amount, appealing a revision in the contingency tariff because of the nature of his client activity - a school ${ }^{97}$.

Nonetheless, as considered by the Court, the water consumption evaluation was based on the consumption during the entire year and not only the holidays. The Court also understood that schools were not part of the contingency tariff exceptions provided by the ARGESP Deliberation n-545 of January 07,2015 . In this sense, neither contracts particularities nor the nature of the activity supplied with water were considered as exclusions ${ }^{98}$. It also shows that, the contingency tariff was applied to all contracts, and it did not consider individual particularities of each contract, except those expressed in regulation, prevailing public interest of water contingency.

There is a problem of environmental equity ${ }^{99}$ concerning the different contracts aimed at different types of consumers. Environmental equity can relate to the adoption of measures to ensure sustainability, usually market mechanisms, due

\footnotetext{
95 The SP District Prosecutor. "Manifestação" DAJD, protocol CGA/SAAD n44/2015. Available at: https://www.pdf-archive.com/2015/02/02/decis-o-sic-607911415364-sabesp/decis-o-sic607911415364-sabesp.pdf.

96 SABESP. Notícias: Contratos de demanda firme, 10.03.2015. Available at: "http://site.sabesp.com.br/site/imprensa/noticias-detalhe.aspx?secaold=66\&id=6480". Also: Lista de contratos fornecida por Agência de jornalismo investigativo: http://apublica.org/contratossabesp/.

97 The Court of Justice of São Paulo, Appeal no 1075940-23.2015.8.26.0100, 28 Chamber of Private Law. Rapporteur: Bonilha Filho, Judment date, 09/28/2017.

98 The Court of Justice of São Paulo, Appeal no 1075940-23.2015.8.26.0100, 28 Chamber of Private Law. Rapporteur: Bonilha Filho, Judment date, 09/28/2017.

99 BEDER, Sharon. Costing the Earth: Equity, Sustainable Development and Environmental Economics. in. New Zealand Journal of Environmental Law. vol. 4. 2000, p. 227-243.
} 
to the levels of scarcity that a natural resource present. However, when these measures are not applied with due consideration to the particularities of each of the users, they can reinforce or even create inequalities among the final beneficiaries.

Environmental equity proposes that measures should be applied in an impartial, balanced, and equitable manner for the configuration of guaranteed access and opportunity of the resource ${ }^{100}$. In São Paulo, two factors contradict these parameters: first, water rationing for some and maintaining consumption levels for others, and second, the fact that those who use water for human supply (adhesion contracts) were paying more than those who use it for commercial purposes (firm demand contracts).

In addition, water pricing tariffs have been revised in an extraordinary way to ensure the financial and economic balance of the supply service, even though water consumption has been reduced.

\section{c. The legality of the extraordinary revision of SABESP tariff for water provision during the crisis}

Another result of the crisis was the need to adjust the ordinary tariff for water supply because of the cumulative costs that SABESP was having since water consumption had decreased. The revision was authorized by the ARSESP Deliberation $\mathrm{n}^{\circ} 561$ of Mai $04,2015^{101}$. The revision itself was questioned ${ }^{102}$, giving the fact that SABESP had contributed to the decline of the demand for water consumption. It was also questioned because it was made extraordinarily, that is, the revision was not made in accord with its ordinary process ${ }^{103}$.

\footnotetext{
${ }^{100}$ BRAVO, Álvaro A. Sánchez. Derecho Humano al Agua. In: PURVIN, Guilherme (Org.). Direito Ambiental, Recursos Hídricos e Saneamento. Estudos em comemoração aos 20 anos da Política Nacional de Recursos Hídricos e aos 10 anos da Política Nacional de Saneamento. 1 ed. São Paulo: Letras Jurídicas, pp.48-49.

101 ARSESP Deliberation $\mathrm{n}^{\circ} 561$ of Mai 04, 2015. Available at: https://www.legisweb.com.br/legislacao/?id=284250

102 The Court of Justice of São Paulo, Appeal no 1016142-78.2015.8.26.0053, 11 Chamber of Public Law. Rapporteur: Marcelo L Theodósio, Judment date: 26/09/2017.

${ }^{103}$ The ordinary mechanisms are provided at the article 38 of the Basic Sanitary Law. Federal Law $\mathrm{n}^{\circ}$ 11.445, of January 5, 2007, English version. Available at: http://www.sabesp.com.br/sabesp/filesmng.nsf/51E5FECA4D2D70A38325772300657DC5/\$File /law_11445.pdf
} 
Withal, the SP Court understood that the extraordinary revision was legal. As explained by the Judge, the Regular Tariff Review carried out periodically, and the Annual Tariff Adjustment, are both mechanisms used by the Regulatory Agency to update tariffs. However, unforeseen events, may require the regulatory agency to reassure the financial and economic balance of the concession ${ }^{104}$. In this sense:

Article 38. The tariff revisions shall comprise the reassessment of the conditions for the rendering of services and tariffs practiced and may be:

I - periodic, aiming at the distribution of productivity gains with users (...)

II - extraordinary, when events occur that are not foreseen in the contract, beyond the control of the service provider, that alter their economic-financial balance. "105

From the consumer's point of view, it is not logical that the tariff can be changed and increased because consumption had diminished. It was exactly the purpose of all contingency measures: to reduce water consumption. Nevertheless, the extraordinary revision is legal if justified, because it is provided as a balance instrument to public service providers.

Water management is grounded in economic approaches to rationalize the use of the resource. Pricing is used as an important tool to equate scarcity with economic value, aiming at rational use by final recipients. However, such administrative measures play uncertain roles in the practical results of physical

\footnotetext{
104 The Court of Justice of São Paulo, Appeal no 1016142-78.2015.8.26.0053, 11를 Chamber of Public Law. Rapporteur: Marcelo L Theodósio, Judment date: 26/09/2017.

${ }^{105}$ From the original: "Art. 38. As revisões tarifárias compreenderão a reavaliação das condições da prestação dos serviços e das tarifas praticadas e poderão ser: I - periódicas, objetivando a distribuição dos ganhos de produtividade com os usuários e a reavaliação das condições de mercado; II - extraordinárias, quando se verificar a ocorrência de fatos não previstos no contrato, fora do controle do prestador dos serviços, que alterem o seu equilíbrio econômico-financeiro." Article 38. Federal Law o 11.445, of January 5, 2007, English version. Available at: http://www.sabesp.com.br/sabesp/filesmng.nsf/51E5FECA4D2D70A38325772300657DC5/\$File /law_11445.pdf
} 
water allocation for large consumers and individual users, due to economic asymmetries $^{106}$.

In this context, it is important to emphasize that payment for services should not become an obstacle to the right of access to water ${ }^{107}$. The tariff should be modest, in such a way that it does not limit users' ability to pay for other essential goods or services such as housing, education and health. In this sense, realizing the human right of access to water is also ensuring that financial subsidies for the execution of services are accessible to all users, and in a country of extreme economic inequality such as Brazil, this dimension is particularly important.

\section{FINAL REMARKS}

Legally, to provide a public service with the use of private tools and the participation of private actors is a challenge. It is not water privatization, since it is not a free water market, and it is ruled under public law regulation. However, it may suffer the private logic repercussions that come with a private entity. It may occur, for example, when the private actor requests the protection of the contract terms. In the meanwhile, public services require public information and not confidential, the primacy of the public interest and not of the private interest, a continuous and universal access and not limited access.

On the one hand, in the São Paulo case there were numerous efforts on controlling the crisis. The control of the water available was made (considering ANA and DAEE restrictions), an incentive program established, the contingency tariff that came later was also coherent with the need to reduce consumption and there was the need to adjust tariff because of the crisis.

On the other hand, especially in 2014, there was a lack of consistency of information provided to consumers about rationing measures. While management agencies were progressively imposing restrictions to SABESP, an incentive program for reductions in water consumption was running and

\footnotetext{
${ }^{106}$ ZHOU, Qing. et. al. Management Innovation for Integrated River Basin Management. in: Deng, Xiangzheng; Gibson, John. (eds). River Basin Management. Ecohydrology. Singapura: Springer, 2018, p. 4.

107 UNITED NATIONS COMMITTEE ON ECONOMIC, SOCIAL AND CULTURAL RIGHTS. General Comment No. 15: The right to water (articles 11 and 12 of the International Covenant on Economic, Social and Cultural Rights), 2002.
} 
complains about the absence of water supply were increasing. Nevertheless, rationing measures were formally proclaimed only in January 2015 , with the Deliberation 545 of January 8, 2015.

Transparency in rationing measures regulation is what it is expected from the authorities, especially because it results in water privation. If these measures were applied without notification, violation of human rights is characterized, and compensation should be provided. However, this was not the major understanding in São Paulo's Court of Justice, and because of that, there is the possibility that its interpretation of the issue is incomplete. Most compensation claims were denied because the water crisis was considered as a major force fact which removes the duty to compensate in the case of a damage. The civil liability for state actions has the major force fact, as one of the possibilities of excluding state liability. It is not this reasoning that it is criticized, but the legality of rationing measures that were not fully explained to consumers.

This also affects information about contracts. Because private interest must be respected, there is the need to provide main rules on how information can be provided so that transparency is improved. Finally, concerning the extraordinary revision of the tariff, it can also be better explained so its legality and necessity becomes clearer.

Without a clear regulation, both the State duties and company assignments are affected: the establishment of tariffs and other monetary measures may not be disconnected since anomalies in tariffs and contracts may occur and water contingency may lead into an irregular to the point that it may violate the principles of the continuity of essential services and of the primacy of the public interest.

The action of providing the public service of water supply is not only related to human rights, but also the to the state duties and consumers civil rights. It includes not only the right to access water, but the right to receive a public service with quality, the right to receive information about the water conditions - especially in a crisis situation -, and the right to compensation in case of violations. It increases the importance of improving the application of legal guaranties instruments such as the civil liability whenever these human rights are transgressed. In this sense, if there is no adaptation of the rules of civil liability 
related to water supply in cases of water crisis, the right to access water as a human right may be jeopardized.

Furthermore, civil liability related to water supply and a scarcity situation should be revised. Currently, the civil liability rules for state actions has the major force status of natural disasters facts as one of the fundaments to exclude state liability. Water crisis was considered as a major force so that the responsible for the water supply was not hold liable for its omissions. This lacks adaptation regarding the possibility to characterize water privation as an environmental damage.

In the case of São Paulo, water privation was proved to be not only because of the water scarcity crisis, but also because problems of communication, the lack of transparency and water management. In that sense, water privation could also be considered as an environmental damage under the strict liability theory based on consumers and environmental rights - articles 12 and 14 of the Federal Law $\mathrm{n}^{\circ} 8.078 / 1990$ and $\S 1^{\circ}$ of the article 14 from the Federal Law $\mathrm{n}^{\circ} 6.938 / 1981$. This would improve the relationship between the human right to water and the duty to provide the public service of water supply within the principles of transparency, information, and efficiency.

\section{BIBLIOGRAPHY}

\section{Legal Norms and public regulation acts}

\section{International Law}

The United Nations Water Conference in "Mar del Plata”, 1977 (A / RES / 32/158);

The Dublin Statement on Water and Sustainable Development, International Conference on Water and the Environment, 1991 (A/CONF.151/PC/112);

The United Nations Environmental Conference in Rio de Janeiro, 1992.

The United Nations Resolution 64/292 The Human Right to Water and Sanitation. UN General Assembly Resolution A/RES/64/292, 2010. 
The United Nations Human Rights Council (UNHR). Report of the Special Rapporteur on the human right to safe drinking water and sanitation (On Affordability). UN Document A/HRC/30/39, 2015.

\section{$\underline{\text { National Law }}$}

Federal Constitution of 1988

Federal Law ํㅜ 6.938/1981

Federal Law nำ 8.078/1990

Federal Law no 9.433/1997

Federal Law no 11.445/2007

Federal Law no $14.026 / 2020$

The State of São Paulo Law n 119/1973, restructured by the State of São Paulo Law nํㅡ Law nำ16.525, of September 15, 2017.

The State of São Paulo Law no 16.525, of September 15, 2017. Available at: http://www.sabesp.com.br/sabesp/filesmng.nsf/49D32E3FC45C9A92832581B0 005478F0/\$File/law_16525_september_2017.pdf

\section{National Regulation Acts}

ARSESP. Deliberação n. 106 de 2009, Art. 2ํ․ XVII. Disponível em: "http://site.sabesp.com.br/uploads/file/clientes_servicos/deliberacao_arsesp106 _13112009.pdf".

ARSESP. Deliberation $\mathrm{n}-469$ of February 3, 2014. Available at: http://www.arsesp.sp.gov.br/LegislacaoArquivos/ldl4692014.pdf

ARSESP Deliberation $\mathrm{n}-480$ of March 31,2014. Available at: http://www.arsesp.sp.gov.br/LegislacaoArquivos/ldl4802014.pdf

ARSESP Deliberation $\mathrm{n} \div 514$ of October 24, 2014. Available at: http://www.arsesp.sp.gov.br/LegislacaoArquivos/ldl5142014.pdf

ARSESP Deliberation $\mathrm{n} \div 615$, of December 23, 2015. Available at: http://www.arsesp.sp.gov.br/LegislacaoArquivos/ldl6152015.pdf 
ARSESP Deliberation no 545 of January 8, 2015, articles 2 and 3. Available at: http://www.arsesp.sp.gov.br/LegislacaoArquivos/ldl5452015.pdf

ARSESP Deliberation $\mathrm{n}^{\circ} 561$ of Mai 04, 2015. Available at: https://www.legisweb.com.br/legislacao/?id=284250

BRAZIL, The Federal Constitution. Available at: http://www.planalto.gov.br/ccivil_03/Constituicao/Constituicao.htm

DAEE, Portaria do Superintendente DAEE-2617, de 17-8-2015, publisted at: Diário Oficial, Poder Executivo, Seção I, terça-feira, 18 de agosto de 2015, available

at:

https://www.imprensaoficial.com.br/DO/BuscaDO2001Documento_11_4.aspx?li nk=/2015/executivo\%2520secao\%2520i/agosto/18/pag_0052_F0IA3O1JBVME 8eC5E71G6I65LP9.pdf\&pagina=52\&data=18/08/2015\&caderno=Executivo\%20I \&paginaordenacao $=100052$

Joint Communication of ANA and DAEE nำ230, of March 6, 2014, available at: http://arquivos.ana.gov.br/institucional/sof/GTAG-

Cantareira/20140306_Comunicado_ANA_DAEE_n_230.pdf

Joint Communication of ANA and DAEE $\mathrm{n}-237$, of July 1, 2014. Available at: http://arquivos.ana.gov.br/institucional/sof/GTAG-

Cantareira/20140701_Comunicado_ANA_DAEE_237.pdf

Joint Communication of ANA and DAEE n243, of March 5, 2015. Available at: http://arquivos.ana.gov.br/imprensa/noticias/20150306042504_Oficio\%20SUP \%20394\%20DAEE.pdf

The Consumers Protections Law. BRAZIL. Federal Law no. 8.078 / 1990. Available at: http://www.planalto.gov.br/ccivil_03/LEIS/L8078.htm

The National Policy on Water Resources. BRAZIL, Federal Law no 9.433 of 1997. Available at: https://www.planalto.gov.br/ccivil_03/LEIS/L9433.htm

The Federal Law ํo 11.445, of January 5, 2007, English version. Available at: http://www.sabesp.com.br/sabesp/filesmng.nsf/51E5FECA4D2D70A383257723 00657DC5/\$File/law_11445.pdf

The National Council of Water Resources. Resolution n16/2001. Available at: http://www.cnrh.gov.br/index.php?option=com_content\&view=article\&id=14 
The State of São Paulo Law n 119/1973, restructured by the State of São Paulo Law no Law nำ16.525, of September 15, 2017.

The State Law $\mathrm{n}^{-}$16.525, of September 15, 2017. Available at: http://www.sabesp.com.br/sabesp/filesmng.nsf/49D32E3FC45C9A92832581B0 005478F0/\$File/law_16525_september_2017.pdf

The state of São Paulo Decree $\mathrm{n}^{\circ} 41.446$ / 1996. Available at: http://site.sabesp.com.br/uploads/file/clientes_servicos/decreto_estadual\%2041 446_pdf.pdf

\section{Jurisprudence and Civil Inquiries}

The Federal Supreme Court. "Ação Civil Ordinária” n² 2536. Rapporteur Minister Luiz Fux. Decision published at 06.15.2015, available at: http://www.stf.jus.br/portal/processo/verProcessoAndamento.asp?incidente=46 56331

The Federal Superior Court of Justice, Direct action of unconstitutionality $\mathrm{n}^{\circ}$ 1.950, Rel. Min. Eros Grau, j. 3-11-2005, P, DJ de 2-6-2006.

The Federal Superior Court of Justice. REsp 1.328.753-MG, Rel. Min. Herman Benjamin: 28/5/2013.

The Court of Justice of São Paulo, 2o Chamber. Interlocutory appeal (from Portuguese "Agravo de Instrumento") no 2235792-75.2015.8.26.0000, rapporteur: Eutálio Porto. Date of the Judgement: 14/04/2016. Available at: https://esaj.tjsp.jus.br/cjsg/getArquivo.do?cdAcordao=9368152\&cdForo=0

The Court of Justice of São Paulo, 2o Chamber. Interlocutory appeal (from Portuguese "Agravo de Instrumento") no 2235792-75.2015.8.26.0000, rapporteur: Eutálio Porto. Date of the Judgement: 14/04/2016. Available at: https://esaj.tjsp.jus.br/cjsg/getArquivo.do?cdAcordao=9368152\&cdForo=0

The Court of Justice of São Paulo, 11ª Chamber of Public Law. Public Civil Action no 1016142-78.2015.8.26.0053, SP. Rapporteur: Marcelo L Theodósio, Judgment day: 26/09/2017, publication: 27/09/2017. 
The Court of Justice of São Paulo, 28 Chamber of Private Law. Appeal oo 1075940-23.2015.8.26.0100, Equitable claim (in Portuguese is an "Ação de Obrigação de fazer com repetição in debito"), Rapporteur: Bonilha Filho, Judment day 09/28/2017. Available at: https://esaj.tjsp.jus.br/cjsg/getArquivo.do?cdAcordao $=10838233 \& \mathrm{cdForo}=0$

The Court of Justice of São Paulo: APL: 10131972120158260053 SP Relator: Paulo Galizia, Data de Julgamento: 19/10/2015, 10ª Câmara de Direito Público, Data de Publicação: 21/10/2015.

The Court of Justice of São Paulo: Appeal № 1015295-87.2015.8.26.0114, 24 Chamber of Private Law. Rapporteur: Jonize Sacchi de Oliveira, Judgment day: 14/12/2017;

The Court of Justice of São Paulo: Appeal oㅜ 1015395-42.2015.8.26.0405, 28을 Chamber of Private law. Rapporteur: Gilson Delgado Miranda, Judment day: 24/01/2018;

The Court of Justice of São Paulo: Appeal oㅜ 1011677-90.2015.8.26.0161, 13ำ Chamber of Private Law. Rapporteur: Francisco Giaquinto, Judment day: 07/07/2017;

The Court of Justice of São Paulo: Appeal oㅜ 1005907-67.2014.8.26.0609, 30은 Chamber of Private Law. Rapporteur: Penna Machado, Judment day: 14/12/2016;

The Court of Justice of São Paulo: Appeal no 1000459-71.2015.8.26.0547; 10 Chamber of Public Law. Rapporteur: Paulo Galizia; Judment Day: 05/03/2018;

The Court of Justice of São Paulo: Appeal no 1000459-71.2015.8.26.0547.

The Court of Justice of São Paulo. "Agravo de Instrumento" no 220789254.2014.8.26.0000, 5 $5^{\mathrm{a}}$ Chamber of Public Law. Rapporteur: Fermino Magnani Filho, judment day: 23/07/2015.

The Court of Justice of São Paulo, Appeal № 1075940-23.2015.8.26.0100, 28 Chamber of Private Law. Rapporteur: Bonilha Filho, Judment day, 09/28/2017.

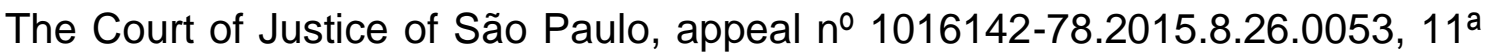
Chamber of Public Law. Rapporteur: Marcelo L Theodósio, Judment day: 26/09/2017. 
The Court of Justice of São Paulo. Appeal oㅜ 1015395-42.2015.8.26.0405, 28 Chamber of Private Law. Rapporteur: Gilson Delgado Miranda, Judment day: 24/01/2018.

The Court of Justice of São Paulo. Appeal no 1005907-67.2014.8.26.0609, 30ª Chamber of Private Law. Rapporteur: Penna Machado, Judment day: 14/12/2016.

The Federal Supreme Court. Direct action of unconstitutionality no 1.842 , rel. $\mathrm{p} /$ o ac. Min. Gilmar Mendes, j. 6-3-2013, P, DJE from September 16, 2013

The São Paulo state Prosecutor's Office. Civil Inquiry no 43.0739.0005266/20146, May $2014 . \quad$ Available at: http://www.mpsp.mp.br/portal/page/portal/comunicacao/Newsletter/imagens_ne wsletter/14.0739.0005266-2014-8.pdf

The Inquiry was latter attached to the Civil Inquiry 14.0482.0000231/2014-1, still in course. The São Paulo state Prosecutor's Office. Civil Inquiry $n^{\circ}$ 14.0482.0000231/2014-1. Available at: https://sismpconsultapublica.mpsp.mp.br/Detalhe/140482000023120141

The São Paulo state Prosecutor's Office. Civil Inquiry no 14.0306.0001462/20142, established on July 23, 2014. Available at: http://www.mpsp.mp.br/portal/page/portal/comunicacao/Newsletter/imagens_ne wsletter/14.0306.0001462-2014-2.pdf

The São Paulo state Prosecutor's Office. Civil Inquiry nº14.161.749/14. Available at:

http://www.mpsp.mp.br/portal/page/portal/comunicacao/Newsletter/imagens_ne wsletter/14.0161.0000749-2014.pdf

The SP Prosecutor. "Manifestação" DAJD, protocol CGA/SAAD n44/2015. Available at: https://www.pdf-archive.com/2015/02/02/decis-o-sic607911415364-sabesp/decis-o-sic-607911415364-sabesp.pdf.

\section{Doctrine, articles and news}

BARROS, Ana Cláudia. Levantamento aponta 618 reclamações de falta de água na capital e na Grande São Paulo. R7, 01 de outubro de 2014. Available at: 
https://noticias.r7.com/sao-paulo/levantamento-aponta-618-reclamacoes-defalta-de-agua-na-capital-e-na-grande-sao-paulo-09102014

BEDER, Sharon. Costing the Earth: Equity, Sustainable Development and Environmental Economics. in. New Zealand Journal of Environmental Law. vol. 4. 2000.

BORRÀS, S. New Transitions from Human Rights to the Environment to the Rights of Nature. Transnational Environmental Law, 5(1), 113-143. 2016.

BRESSER PEREIRA, Luiz Carlos. Da administração pública burocrática à gerencial. In: Revista do Serviço Público. № 47 (1), janeiro/abril de 1996. Brasília: $\begin{array}{lllll}1996 . & \text { p. } & 6 . & \text { Disponível }\end{array}$ http://www.bresserpereira.org.br/papers/1996/95.AdmPublicaBurocraticaAGere ncial.pdf

CARTA CAPITAL. Crise hídrica: As cinco perguntas que a Sabesp se recusa a responder, 25.02.2015. Disponível em: http://www.cartacapital.com.br/sociedade/as-cinco-perguntas-que-a-sabesp-serecusa-a-responder-2858.html.

DIAS, Natália. O sistema Cantareira e a crise da água em São Paulo [livro eletrônico]: falta de transparência, um problema que persiste. Coordenadora Mariana Tamari. -- São Paulo: Artigo 19 Brasil, 2016. Available at: http://artigo19.org/wp-content/blogs.dir/24/files/2016/06/Sistema-Cantareira-e-aCrise-da-\%C3\%81gua-em-S\%C3\%A3o-Paulo-2.pdf

DIETZ, Thomas; OSTROM, Elinor; STERN, Paul C., The Struggle to Govern the Commons. Science, 00368075, 12/12/2003, Vol. 302, ㄲo 5652.

FERRAÇO, André Augusto Giuriatto. A Insuficiência de Integração na Gestão Nacional dos Recursos Hídricos Brasileiros como Óbice Estrutural ao Desenvolvimento Sustentável. Dissertação - Mestrado em Direito. Universidade de Brasília, 2019.

FROTA, Hidemberg Alves da. O princípio da supremacia do interesse público sobre o privado no direito positivo comparado: expressão do interesse geral da sociedade e da soberania popular. Revista de Direito Administrativo, Rio de Janeiro, v. 239, p. 45-66, jan. 2005. 
FURTADO, Lucas Rocha. Curso de Direito Administrativo. Belo Horizonte: Fórum, 2007, p.1007.

G1. Moradores reclamam de falta d'água e pedem 'racionamento oficial' em SP, 15 de outubro de 2014. Available at: http://g1.globo.com/saopaulo/noticia/2014/10/moradores-reclamam-de-falta-dagua-e-pedemracionamento-oficial-em-sp.html HERSCOVICI, Alain, "Escolha coletiva, governança e direitos de propriedade: uma análise econômica dos commons", Nova econ. [online]. 2013, vol.23, n.1, p. 192-193, Available at: http://www.scielo.br/pdf/neco/v23n1/07.pdf

HOWARTH, William. Water pollution and water quality. In: In: RIEU-CLARKE, Alistair; ALLAN, Andrew; HENDRY, Sarah (Eds.) Routledge Handbook of Water Law and Policy. New York: Routledge Handbooks, 2017, p. 79.

JACOBI, P. R.; CIBIM, J.; LEÃO, R. de S. "Crise hídrica na Macropetrópole Paulista e respostas da sociedade civil", Estudos Avançados 29 (84), 2015, available at: http://www.scielo.br/pdf/ea/v29n84/0103-4014-ea-29-84-00027.pdf LANGFORD, Malcolm; RUSSELL, Anna F. S. The Right to Water in Context. In: LANGFORD, Malcolm; RUSSELL, Anna F. S. (Eds.) The Human Right to Water. Cambridge University Press, 2017.

LANGFORD, Malcolm; BARTRAM, Jamie; ROAF, Virginia. The Human right to Sanitation. In: LANGFORD, Malcolm; RUSSELL, Anna F. S. (Eds.) The Human Right to Water. Cambridge University Press, 2017.

LEITE, José Rubens Morato; AYALA, Patryck de Araújo. Dano ambiental: do individual ao coletivo extrapatrimonial. Teoria e Prática. 5 ed. São Paulo: Editora Revista dos Tribunais, 2014.

LEUZINGER, Márcia Dieguez; COUTINHO, Gabriel Leuzinger; SILVA, Solange Teles da. Repartição de competências legislativas e materiais no âmbito dos recursos hídricos. In: PURVIN, Guilherme (Org.). Direito Ambiental, Recursos Hídricos e Saneamento. Estudos em comemoração aos 20 anos da Política Nacional de Recursos Hídricos e aos 10 anos da Política Nacional de Saneamento. 1 ed. São Paulo: Letras Jurídicas, 2017. 
LOIOLA, Suyanne Soares. Princípio da continuidade do serviço público e a suspensão no caso de inadimplência do consumidor. Revista Jurídica UNIGRAN. Dourados, MS | v. 15 | n. 30 | Jul./Dez. 2013.

MACHADO, Paulo Affonso Leme. Direito de acesso à água. São Paulo: Malheiros, 2018.

NOBRE, C.; SAMPAIO, G.; SALAZAR, L., "Mudanças climáticas e Amazônia", Mudanças Climáticas Artigos, p.22-27, available at: http://docplayer.com.br/5709846-As-influencias-do-homem-no-equilibrionatural-do-planeta.html ;

OSTROM, Elinor, "A diagnostic approach for going beyond panaceas", Proc Natl Acad Sci, 2007, September 25; 104(39), p. 15181-15182.;

REDE BRASIL ATUAL. Sabesp divulga contratos censurados de demanda firme em seu site, 12 de março de 2015. Available at: https://www.saneamentobasico.com.br/sabesp-divulga-contratos-censuradosde-demanda-firme-em-seu-site/

SABESP. Situação dos Mananciais. Available at: http://www2.sabesp.com.br/mananciais/DivulgacaoSiteSabesp.aspx SABESP. Crise Hídrica, Estratégia e Soluções da Sabesp, 04.30.2015. Available at:

http://site.sabesp.com.br/site/uploads/file/crisehidrica/chess_crise_hidrica.pdf

SABESP. Perfil. Available at: http://site.sabesp.com.br/site/interna/Default.aspx?secaold=505

SABESP. Crise Hídrica, Estratégia e Soluções da Sabesp, 04.30.2015, p.13. Available at: http://site.sabesp.com.br/site/uploads/file/crisehidrica/chess_crise_hidrica.pdf SORIANO, E.; LONDE, L. de R.; DI GREGORIO, L. T.; COUTINHO, M. P.; SANTOS, L. B. L., "Crise hídrica em São Paulo sob o ponto de vista dos desastres", Ambiente \& Sociedade, São Paulo v. XIX, n. 1, p. 21-42, jan.-mar. 2016, available at: http://www.scielo.br/pdf/asoc/v19n1/pt_1809-4422-asoc-1901-00021.pdf 
STEIGLEDER, Annelise Monteiro. Responsabilidade civil ambiental: as dimensões do dano Ambiental no Direito Brasileiro. 3 ed. Revista e Atualizada. Porto Alegre: Editora Livraria do Advogado, 2017.

TARLOCK, A. Dan. Water allocation and management during drought. In: RIEUCLARKE, Alistair; ALLAN, Andrew; HENDRY, Sarah (Eds.) Routledge Handbook of Water Law and Policy. New York: Routledge Handbooks, 2017, p. 155-156.

The São Paulo state Prosecutor's Office. Consulta de Procedimentos. Available at:

https://sismpconsultapublica.mpsp.mp.br/ConsultarProcedimentos/ObterProced imentos . The Federal Prosecutor's Office. São Paulo water Crisis. Public Audience, July, 2015. Available at: http://www.mpf.mp.br/atuacaotematica/ccr4/dados-da-atuacao/eventos/audiencia-publica/audiencia-publicacrise-hidrica-sp/editalaudienciapublica_crise_SP.pdf

VOLDOIRE, A.; ROYER, E. J. F., "Tropical deforestation and climate variability", Climate Dynamics, v. 22, p. 857-874. 2004.

ZIEGLER, M. F. "Cinco razões (que não a falta de chuva) para explicar a crise hídrica em SP", IG, 25 February, 2015, available at: http://ultimosegundo.ig.com.br/brasil/2015-01-25/cinco-razoes-que-nao-a-faltade-chuva-para-explicar-a-crise-hidrica-em-sp.html

SABESP. Notícias: Contratos de demanda firme, 10.03.2015. Available at: "http://site.sabesp.com.br/site/imprensa/noticiasdetalhe . aspx? secaold=66\&id=6480".

SABESP. Lista de contratos fornecida por Agência de jornalismo investigativo: http://apublica.org/contratos-sabesp/ . 